\title{
A review of the serotonin transporter and prenatal cortisol in the development of autism spectrum disorders
}

\author{
Roselyn Rose'Meyer
}

\begin{abstract}
The diagnosis of autism spectrum disorder (ASD) during early childhood has a profound effect not only on young children but on their families. Aside from the physical and behavioural issues that need to be dealt with, there are significant emotional and financial costs associated with living with someone diagnosed with ASD. Understanding how autism occurs will assist in preparing families to deal with ASD, if not preventing or lessening its occurrence. Serotonin plays a vital role in the development of the brain during the prenatal and postnatal periods, yet very little is known about the serotonergic systems that affect children with ASD. This review seeks to provide an understanding of the biochemistry and physiological actions of serotonin and its termination of action through the serotonin reuptake transporter (SERT). Epidemiological studies investigating prenatal conditions that can increase the risk of ASD describe a number of factors which elevate plasma cortisol levels causing such symptoms during pregnancy such as hypertension, gestational diabetes and depression. Because cortisol plays an important role in driving dysregulation of serotonergic signalling through elevating SERT production in the developing brain, it is also necessary to investigate the physiological functions of cortisol, its action during gestation and metabolic syndromes.
\end{abstract}

Keywords: Autism spectrum disorder, Cortisol, Serotonin, SERT

\section{Review}

\section{Definition of autism spectrum disorder}

Autism spectrum disorder (ASD) is a neurodevelopmental disorder presenting in the first 3 years of life that is strongly correlated with changes in neural growth during prenatal and post natal periods [1]. A child with ASD presents with the following: defects in social interaction and communication [2]; repetitive stereotypic behaviour or movements [2]; deficits in language acquisition [3], failure to assume meaning from normal social cues and a fixation on a maintained uniformity of routine [4]. Furthermore, this disorder is also associated with sensory abnormalities with a low threshold to sensory inputs that result in avoidance behaviours [5]. ASD is generally viewed as a male predominant disorder with a ratio of 4:1 to females [6].

Autism is classified as a pervasive developmental disorder and clinicians and researchers use the term ASD to include autism, Asperger's syndrome and pervasive

Correspondence: r.rosemeyer@griffith.edu.au

School of Medical Sciences, Griffith University, Gold Coast Campus, Parklands Drive, Southport, Queensland 4222, Australia developmental disorder not otherwise specified (PDDNOS) (for review of symptoms see [2]). The primary symptoms of ASD have previously been defined in the Diagnostic and Statistical Manual of Mental Disorders, 4th Edition (DSM-IV, American Psychiatric Association) with some impairments controversially reclassified in the recently released DSM-V [7].

Over the past 20 years there has been an increase in the frequency of the disorder with present rates of ASD being diagnosed at about $2 \%$ for children in the USA [8]. A number of reasons have been advanced for this increase, including changes in administrative classifications, policy and practice changes and increased awareness [2]. It is believed that surveillance and screening strategies for early identification of ASD could allow early treatment and improved outcomes.

Nevertheless, hereditary and environmental factors that occur during gestation and postnatal periods leading to significant aberrations in neural organisation and cortical network development are the most likely causes of ASD [9]. 


\section{Diagnosis of autism spectrum disorder}

It has been difficult to diagnose ASD until the affected child is 3 years of age, as the clinical signs are not easily identifiable and language development is delayed [2]. Some families report social deficits (such as facial expressions, non-verbal gestures and reduced interaction) within the first few months after birth [10]. A retrospective video study published by Baranek in 1999 [11] observed the symptoms of ASD in children at 9 to 12 months and has suggested a number of early intervention procedures that involve assessment of sensory processing and sensory motor functions in addition to recording social responsiveness during infancy to diagnose ASD. Studies investigating infants at risk (siblings of affected children) have reported that deficits in communication and social interactions can be identified as early as 6 months of age $[12,13]$. These observations indicate that relevant neurochemical events that alter neuroanatomical growth occur early in the development of the CNS (central nervous system) [14]. Therefore, it is suggested that if we can understand the combination of events that cause the development of ASD, then we can identify women and children at risk and conceivably develop treatments to reduce symptoms associated with this condition.

\section{Aetiology of ASD}

A combination of clinical, neuroimaging, neuropathological and neurochemical studies of individuals diagnosed with ASD have reported disorders in the neuronal cortical organisation causing deficits in information processing in the nervous system [15]. This includes alterations in neural synaptic and dendritic organisation that modifies brain structure, coupled with abnormal patterns of brain growth during the early years in brain regions involved in the development of social, communication and motor abilities [9].

ASD has been shown to be a highly genetic disorder. Heritability estimates from family and twin studies suggest that about $90 \%$ of variance is attributable to genetic factors [16], with 60 to $92 \%$ of monozygotic twins concordant for ASD (depending on the symptoms) compared to $10 \%$ of dizygotic twins [17]. The risk of developing ASD has recently been estimated to be $18.7 \%$ for siblings of individuals diagnosed with ASD. This reoccurrence risk is higher than previously reported rates of 3 to $10 \%$, once data which have been distorted due to families who stop having children once a child has been diagnosed with the developmental disorder have been removed [18].

ASD is recognised as a multifactorial disorder with other risk factors contributing to the phenotype. Studies have shown that serotonin and genetic differences in serotonin transport could contribute to the development of ASD, as serotonin has a vital role in stimulating cell proliferation in the developing brain during pre- and postnatal periods as well as in early childhood [14]. Studies have shown macroscopic and microscopic brain abnormalities may occur in utero and that the pathogenesis of this condition may begin during the prenatal period $[15,19,20]$.

\section{Comorbid conditions and ASD}

Comorbid conditions are common in children and families with ASD. Parents of affected children have increased rates of stress, anxiety and depression [21]. Comorbid behavioural and developmental disorders in people diagnosed with ASD include intellectual delays, inattention, attention-deficit hyperactivity disorder, aggression and disruption, depression or anxiety, sleep disruption or sensory differences [22,23]. Other comorbidities include gastroesophageal reflux, flood selectivity and neurological disorders, such as tics, seizures or migraine [24]. Many of these conditions have been linked to the dysregulation of serotonergic systems [25-34]. Abnormalities in serotonergic function have been linked with ASD since Schain and Freedman reported hyperserotonemia in 1961 [35]. This observation has been confirmed in subsequent studies where in 25 to $33 \%$ of individuals diagnosed with ASD, whole blood serotonin levels were found to be elevated [36]. Furthermore, family members of children diagnosed with ASD with hyperserotonemia also exhibit raised blood serotonin levels [37].

\section{Physiological actions of serotonin and its regulation by serotonin reuptake transporter (SERT)}

Serotonin is synthesised from the essential amino acid L-tryptophan. L-tryptophan is hydroxylated to 5hydroxytryptophan (5-HTP) then decarboxylated by aromatic-L-amino acid decarboxylase to serotonin [38]. Serotonin produced peripherally does not cross the blood-brain barrier of the mature brain and as such, the neurotransmitter has to be synthesized in the CNS. It must be noted, however, that the blood brain barrier is not fully functional in the developing human brain until 2 years of age and it has been hypothesized that elevated platelet serotonin may alter the monamine levels during early brain development in autistic children [39]. After its release from serotonergic neurons, serotonin will bind its receptors at the synaptic site to activate intracellular signalling pathways to induce physiological effects. The actions of serotonin are then terminated when it is rapidly taken up by a SERT. Serotonin is catabolised by the mitochondrial enzyme monoamine oxidase $\mathrm{A}$ to its metabolite 5-hydroxyindolacetic acid (5-HIAA).

The behavioural effects of serotonin are numerous as it regulates mood, appetite, body temperature, arousal, moderates pain sensitivity, sexual behaviour and hormone release [14]. Other than its actions as a neurotransmitter in the CNS, serotonin is released in the 
periphery to mediate a range of physiological activities. The SERT proteins are localised to the presynaptic terminals of the serotonergic neurons [40] and is found in limited places such as the specialised cells of the gut [41], placenta [42], lung [43], pancreas [44] and adrenal chromaffin cells [45], blood lymphocytes [41] and platelets [46]. In the periphery, tissues take up and store serotonin in vesicles where it is released in response to local stimuli [47]. The importance of SERT in regulating normal tissue serotonin levels was demonstrated in SERT-deficient mice, where platelets and most peripheral organs were found to be empty of serotonin. This work showed that there are no compensatory mechanisms such as other monoamine transport systems that could re-establish tissue serotonin levels [47]. Platelets express SERT proteins that are identical to brain SERT [48] and they acquire serotonin released by the enterochromaffin cells as they circulate through the gut. Serotonin captured by platelets have a role in injury where serotonin release can alter blood flow [49] as well as stimulating the production of adhesive alpha-granular proteins in activated platelets [50], and as indicated previously, abnormal levels of platelet serotonin have been observed in ASD-diagnosed children and their relatives. Chronic use of selective serotonin reuptake inhibitors (SSRIs) decrease platelet serotonin content, protects against myocardial infarction or intensifies bleeding episodes [51,52]. Subsequently, excess serotonin uptake may contribute to platelet hyperactivity and thrombosis as reported, with an association of SERT polymorphisms with cardiovascular disease [53]. The presence of SERT proteins on the placental brush border membrane, and the role of serotonin in vascular function indicates that serotonin may have a role in placental function and therefore, growth and development of the human foetus [42]. Serotonin is synthesized by enteric neurons and enterochromaffin cells of the gut where it locally regulates digestive processes $[54,55]$. It can be released into the blood or into the lumen of the gut where it can modify intestinal transport, proliferation of gastrointestinal epithelium and modulation of intestinal motility. Serotonin inhibits gastric acid secretion and may be an endogenous enterogastrone, and stimulates the production and release of gastric and colonic mucus [56]. In the gastrointestinal tract, serotonin acts as a crucial signalling molecule initiating responses such as nausea, vomiting, and peristaltic and secretory reflexes [57]. Serotonin is taken up into the $\beta$-cells of the pancreas, where it is stored in granules that contain insulin to modify insulin release [44].

Serotonin has specific functions in the CNS and in the periphery where it regulates many physiological activities. Problems in serotonergic signalling in some of these systems have been implicated as comorbidities that occur with ASD as discussed in the previous section.
The role of serotonin in neuronal function and development An appreciation of the roles of serotonin as a neurotransmitter and in neuronal growth, particularly during early development, reveals why perturbations in the serotonin signalling systems could contribute to the development of ASD. The serotonergic system is one of the most widely distributed and one of the earliest to develop in the mammalian embryo [58].

In the brain, the majority of serotonergic neurons are located in the median and dorsal raphe nuclei, which project to the cortex or hippocampus, respectively. The cell bodies of the serotonergic neurons are found in clusters, most of which are located in the raphe nuclei of the midbrain, pons and medulla [59]. The serotonergic system innervates virtually all areas of the brain and serotonergic neurons can be detected in the human brain from the fifth gestational week, where they grow and rapidly multiply [60].

With regards to the control of behaviour the two most important clusters of serotonergic neurons are found in the dorsal and medial raphe nuclei, both of which send neuronal projections to the cerebral cortex. As well as its role as a neurotransmitter, serotonin acts as a trophic or differentiation factor in early neurogenesis, where changes in serotonin levels during brain development have been reported to alter neuronal differentiation $[61,62]$.

SERT is a significant contributor to moderating neuronal serotonin levels. There are a significant number of internal and external influences that can alter SERT expression and function from early embryonic stages through to adolescence. And although these influences continue to guide SERT expression and activity throughout adulthood, SERT activity during early periods of human development appear to be vital for guaranteeing normal development [63]. In rodent studies, decreased or increased brain serotonin during the postnatal period of development results in the disruption of synaptic connectivity in sensory cortices in the brain [64-66]. In human studies, serotonin has been demonstrated to be important for prenatal and postnatal brain development [67]. Irregularities in brain serotonin levels can cause asymmetric development of the serotonergic system which leads to incorrectly connecting neural circuits [68]. Changes in serotonergic function and signalling have been found to be associated with ASD [67]. Humans undergo a period of high brain-serotonin synthesis capacity during childhood, a process affected in autistic children [69]. In humans, serotonin activity as measured by the cerebrospinal fluid (CSF) levels of the metabolite 5-HIAA, is higher in children when compared to adults [70,71]. 5HIAA levels in the CSF of children with ASD has been reported to provide a reliable measurement of neural serotonin turnover [14]; however, many studies have indicated a reduction or no change in CSF 5HIAA levels in individuals diagnosed with autistic disorders [72,73]. As such, the 
levels of serotonin metabolites present in the CSF of ASDdiagnosed individuals is still not firmly established, nor is the impact of blood serotonin levels and how they relate to brain serotonin levels [68].

Functional neuro-imaging studies using positron emission tomography (PET) have shown diminished serotonin synthesis in children with ASD between the age of 2 and 5 years [69]. The short-term depletion of Ltryptophan has been shown to exacerbate repetitive behaviour and elevate anxiety in autistic individuals [74], and drug treatment with selective serotonin re-uptake inhibitors, which interact with SERT, have been shown to be effective in decreasing repetitive and/or obsessive behaviour in some but not all autistic individuals [75].

The main issue with the studies investigating 5HIAA levels in the CSF, platelet serotonin or neuronal serotonin synthesis is that they are completed in cohorts of individuals diagnosed with ASD at different ages and growth stages. The role of serotonin in neuronal development changes throughout infancy and childhood as do the environmental factors that can alter serotonergic systems and function.

\section{SERT structure and function}

Intracellular and extracellular serotonin levels are controlled through tissue SERT expression levels and transporter activity. SERT is a protein consisting of 630 amino acids and has a similar structure to the noradrenaline transporter (NET) and dopamine transporter (DAT). In vitro experiments with SERT have demonstrated that phosphorylation state of the transporters is controlled by several kinase and phosphatase signalling pathways which alters movement of serotonin through the transporter [76]. SERT-medicated serotonin uptake is driven by a $\mathrm{Na}^{+} / \mathrm{Cl}^{-}$transmembrane ion gradient [77]. SERT proteins can be regulated by numerous protein kinase (PK) linked pathways, which include the signalling molecules protein kinase $\mathrm{C}(\mathrm{PKC})$, protein kinase $\mathrm{G}$ (PKG) and p38 mitogen-activated protein kinase (MAPK) [78-80]. Extracellular serotonin can induce the phosphorylation and downregulation of SERT through PKC signalling pathways [81]. Several G-protein coupled receptors such as adenosine, histamine and $\alpha_{2}$-adrenergic receptors also modulate SERT activity $[79,82]$ as well as inflammatory cytokines such as IL-10 and IFN- $\gamma$, and TNF- $\alpha$ [83-85]. SERT is the major mechanism by which serotonin uptake from extracellular fluid occurs; however, when SERT function or expression is altered and the levels of serotonin are elevated, other monoamine transporters that have a lower affinity for serotonin such as DAT and NET will transport serotonin [86].

Gain-of-function SERT-coding variants have been reported with some SNPs in the gene that encodes SERT, SLC6A4, causing a change in the amino acid sequence of
SERT [87]. These are rare genetic variants, which represent a frequency of much less that $1 \%$ of the population. Human variants such as Ile425Leu, Phe465Leu and Leu550Val when expressed in HeLa cells have been shown to exhibit a gain of serotonin transport phenotype due to elevated expression of the transporter and altered regulation via the PKG/p38 MAPK signalling pathways [88] whereas the Gly56Ala variant increases in serotonin transport across cell membranes with no changes in transporter numbers [89].

The Gly56Ala variant has been reported to have a higher prevalence in individuals diagnosed with ASD and is associated with both sensory aversion and rigidcompulsive behaviour [90], whereas the Ile425Val variant (albeit the same locus, different amino acid substitution to Ile425Leu) is associated with obsessive-compulsive disorder and Aspergers syndrome [91].

To further investigate the gain of function activity of the Gly56Ala variant in vivo, transgenic mice expressing the SERT Ala56 were developed and exhibited normal growth patterns and fertility [92]. Further studies on the transgenic Gly56Ala mice showed they had increased CNS serotonin clearance, enhanced serotonin receptor sensitivity and hyperserotonemia. The mice also exhibited alterations in social function, communication and repetitive behaviours [93]. Similarly in other transgenic mice, overexpression of the SERT protein caused a reduction in the brain region levels of serotonin and enhanced sensitivity of postsynaptic $5-\mathrm{HT}_{2 \mathrm{~A}}$ receptors was observed [94].

In summary, SERT function is regulated via several signalling systems. When SERT tissue expression increases or SERT function is enhanced, serotonin uptake is increased, which diminishes levels of the neurotransmitter in the synaptic cleft and causes an increase in sensitivity of postsynaptic serotonin receptors to serotonin. In human and animal studies where increased SERT function was observed neurological symptoms similar to those observed in ASD were reported.

\section{Genetics of SERT in ASD}

ASD is a genetically inherited disorder and SERT has been the focus of much research due to its prominent role in serotonin homeostasis. SERT is encoded by the SLC6A4 (Solute carrier family 6 (neurotransmitter transporter, serotonin, member 4) gene. Several gene variants of SLC6A4 that are associated with ASD alter the structure, function or expression of SERT [47]. SERT functions in all serotonergic systems through transport-mediated regulation of serotonin release and activation of homo- and hetero-receptors in brain, platelets and peripheral organs. Changes in the function of SERT alters the affinity and expression of serotonin receptors, as well as the pharmacokinetics of serotonin [47]. Human SLC6A4 maps onto chromosome 17q11.2 [95] and it is one of several genetic 
loci that has been identified as predisposing to ASD $[96,97]$. The gene is composed of 15 exons spanning approximately $40 \mathrm{~kb}$. The sequence of the transcript predicts a protein containing 630 amino acids with 12 transmembrane domains. Alternative promoters and splicing of the code involving exons $1 \mathrm{~A}, \mathrm{~B}, \mathrm{C}$ and the 3' untranslated region results in variable mRNA products. Polymorphisms, which alter the expression of the SLC6A4 gene and therefore, SERT protein levels, have been the focus of research into the genetic inheritance of ASD and as such, polymorphisms within the 5-HTTLPR promoter sequence, mutations in the coding sequence, or intronic mutations of the SERT have been reported to be linked to ASD in some but not all studies $[1,47,89]$. Two major polymorphisms in the SERT gene have been of major interest. First, a variable number of tandem repeats (VNTR) occurs in the second intron of the gene [98]. Second, basal and induced human $S E R T$ gene transcription is differentially modulated by allelic variants of the SERT gene promoter [98]. The SLC6A4 5-HTTLPR promoter sequence is located approximately $1 \mathrm{~kb}$ upstream of the transcription initiation site, contains two variable repeat length polymorphisms known as long (L) with 16 repeat elements, or the 44-base pair (bp) shorter (S) variant with 14 repeat elements $[95,99]$, which determines the expression of the SERT in the pre-synaptic axonic membranes. The $\mathrm{L} / \mathrm{L}$ variant of the 5-HTTLPR promoter region expresses significantly (1.4- to 2.0-fold) more transporter protein compared to L/S or S/S variants [100,101]. Higher SERT mRNA levels and increased serotonin uptake is evident in lymphoblasts of the $\mathrm{L} / \mathrm{L}$ homozygotes compared to those with at least one copy of the $S$ allele [102]. The S/S polymorphism reduces transcriptional efficiency of the SERT promoter to reduce the SERT expression and serotonin uptake in lymphoblasts [102]. Therefore the $\mathrm{L} / \mathrm{L}$ variant was proposed to contribute to a lower concentration in the synaptic cleft, although this is not consistently supported by the literature [100]. The S/S polymorphism has been reported to be associated with psychiatric disorders including neuroticism [99] schizophrenia [103], anxiety [104], depression [105], suicide [106,107], ASD [108] and GI syndromes such as irritable bowel syndrome [109,110].

The $\mathrm{L}$ variant is also correlated with higher rates of serotonin uptake into platelets [111,112], suggesting that the $S$ variant may act as a dominant allele [101]. The results of multiple studies of the 5-HTTLPR and ASD have been inconsistent, showing an association of the short [113-116] or long allele [117,118], and some studies have found no association [119-121].

There is substantial evidence that ASD is genetically inherited and current research has evaluated many polymorphisms that could alter SERT expression in ASD without consistent results, suggesting that the genetic changes associated with SERT have yet to be identified.
At the same time ASD is associated with multiple polymorphisms in the SLC6A4 gene with individuals heterozygous for the Gly56Ala plus 5-HTTLPR L/L promoter variants [73], and other studies into SLC6A4 and other psychiatric disorders suggests that haplotypes (multiple alleles) that include the 5-HTTLPR variants may contribute to this disorder $[122,123]$.

\section{Prenatal conditions and ASD}

Specific maternal illnesses, conditions and treatments can result in adverse neurodevelopmental outcomes in children [124]. Perinatal complications place an infant at significant risk for mental, neurological and behavioural disorders [125]. Maternal metabolic conditions may increase the risk of ASD. Maternal Type 2 diabetes, hypertension, and obesity have been identified as risk factors for ASD and other developmental disorders [124,126]. Prenatal factors such as advanced maternal (and paternal) age, bleeding or gestational diabetes have been associated with the risk of ASD $[127,128]$. An Australian study has linked an increased risk for the development of intellectual disabilities (which included ASD) with maternal asthma [124]. Another report observed that maternal asthma increased the risk of adverse fetal and maternal outcomes such as low birth weight, preeclampsia, hypertensive disorders and gestational diabetes [129]. A high rate of autoimmune diseases occurs in families with ASD indicating that immune dysfunction could combine with other environmental factors in the development of ASD [130]. Parental psychiatric history and prenatal environmental factors also contribute to an increased risk of developing ASD [131].

Prescriptions taken during the pregnancy, length of labour, viral infections, abnormal presentation during birth, and a low birth weight could also be factors that predict outcomes of infantile ASD [125]. Furthermore, the risk of ASD development in preterm babies who are small for their gestational weight is increased, whereas preterm babies who are large for their gestational weight have a reduced risk of ASD [132]. Foetal stress during delivery may also increase the risk of ASD [128]. Overall, epidemiological studies have identified factors including gestational diabetes, stress, infections and inflammatory disorders as prenatal risk factors for ASD. Many of these conditions are known to directly or indirectly elevate cortisol levels [133]. Taking oral corticosteroids during pregnancy confers increased risk of lower birth weight and congenital malformations [129]. Elevated prenatal cortisol is known to negatively affect the behaviour of newborn children with increased irritability, attention and temperament problems [134,135]. Excess plasma cortisol levels have been implicated in the aetiology of comorbid illnesses associated with ASD, such as depression, anxiety, dyspepsia and migraine [136,137] (see Table 1). Furthermore, elevations in plasma cortisol and platelet 
serotonin levels have been observed in schizophrenic patients [138]. Hence, there is evidence to indicate that excess cortisol levels co-exist with serotonin-selective pathologies.

\section{Cortisol regulation}

Cortisol levels rise significantly during gestation and cortisol is an important hormone involved in the development of the fetus. The following sections will review cortisol regulation, physiological actions and its role in metabolic syndromes. The modulation of cortisol by the reproductive hormones and its contribution to gestational diabetes will also be discussed. Glucocorticoids such as cortisol are steroid hormones that are released by the adrenal cortex to regulate carbohydrate metabolism. The hypothalamic release of corticotrophin releasing hormone (CRH) regulates the secretion of adrenocorticotrophic hormone (ACTH) from the anterior pituitary gland, which in turn stimulates the release of cortisol from the adrenal gland. It is a tightly regulated system in which increased plasma cortisol leads to feedback inhibition of both CRH and ACTH [143]. Normal plasma levels of cortisol vary significantly according to the time of day with levels highest in the morning at $0800 \mathrm{~h}$ (138 to $635 \mathrm{mmol} / \mathrm{L})$; at $1600 \mathrm{~h}$ the cortisol level is 83 to $413 \mathrm{mmol} / \mathrm{L}$, and at $2000 \mathrm{~h}$ it is $50 \%$ of the $0800-\mathrm{h}$ level. Urinary cortisol (24-h urine) in children is 5.5 to $74.0 \mathrm{mmol} / \mathrm{L}$ and in adolescents it is 14.0 to $152.0 \mathrm{mmol} / \mathrm{L}$ [139]. The human hypothalamic pituitary adrenal axis (HPA) refers to the hormonal feedback mechanisms that regulate cortisol levels in the body. The HPA is controlled with circadian rhythms [144] and ultradian rhythms with discrete pulses of $\mathrm{ACTH}$ and glucocorticoids to regulate cortisol levels in the body $[144,145]$.

As part of the stress responses many brain regions, including the limbic and sympathetic systems, regulate HPA activity [146,147]. Serotonin can regulate the HPA axis through serotonergic pathways linked to the hypothalamus or hippocampus to stimulate $\mathrm{CRH}$ or $\mathrm{ACTH}$ release or acting as a local paracrine factor in the regulation of cortisol from the adrenal cortex [148,149]. HPA axis dysregulation is caused in part by the release of various inflammatory cytokines, including TNF- $\alpha$, IL-1 and IL-6 where they stimulate CRH production [148].

Cortisol can be inactivated by the enzyme $11 \beta$ hydroxysteroid dehydrogenase (11 $\beta$-HSD)-2, which is found in mineralocorticoid receptor-rich tissues such as the kidney [150] and adipose tissue [151] but not the liver. Cortisol has a high affinity for the mineralocorticoid receptor, however, inactivation to cortisone by $11 \beta$ HSD2 renders it unable to bind to the mineralocorticoid receptor and facilitates aldosterone binding to this receptor [152]. In tissues, including liver, adipose, brain [150] and blood [153], cortisol can be regenerated from its inert form, cortisone, by the enzyme $11 \beta-\mathrm{HSD}-1$
Table 1 Clinical outcomes of tissue-specific glucocorticoid excess [139-142]

\begin{tabular}{|c|c|}
\hline Tissue/system & Symptom \\
\hline \multirow[t]{4}{*}{ Nervous system } & Anxiety \\
\hline & Insomnia \\
\hline & Depression \\
\hline & Memory dysfunction \\
\hline \multirow[t]{2}{*}{ Liver } & Gluconeogenesis \\
\hline & Lipogenesis \\
\hline \multirow[t]{3}{*}{ Skeletal muscle } & Insulin resistance \\
\hline & Atrophy \\
\hline & Fatigue \\
\hline Bone & Osteoporosis \\
\hline \multirow[t]{4}{*}{ Blood } & Elevated blood glucose \\
\hline & Impaired fasting glucose \\
\hline & Hypokalaemia \\
\hline & Dyslipidaemia \\
\hline \multirow[t]{3}{*}{ Adipose tissue } & Obesity \\
\hline & Fat redistribution \\
\hline & Weight gain \\
\hline \multirow[t]{4}{*}{ Cardiovascular system } & Hypertension \\
\hline & Pre-eclampsia \\
\hline & Sodium/water retention \\
\hline & Oedema \\
\hline \multirow[t]{2}{*}{ Immune system } & Immune suppression - infections \\
\hline & Delayed wound healing \\
\hline \multirow[t]{6}{*}{ Skin } & Hirsuitism \\
\hline & Striae \\
\hline & Bruising \\
\hline & Thinning \\
\hline & Acne \\
\hline & Delayed wound healing \\
\hline \multirow[t]{6}{*}{ Other } & Dyspepsia \\
\hline & Increased appetite \\
\hline & Impaired growth in children \\
\hline & Suppressed HPA-axis function \\
\hline & Cataracts \\
\hline & Glaucoma \\
\hline
\end{tabular}

[154]. 11 $\beta-H S D 1$ is a reduced nicotinamide adenine dinucleotide phosphate $(\mathrm{NADP}(\mathrm{H})$ )-dependent microsomal enzyme that converts cortisone into cortisol. Expression of $11 \beta$-HSD1 can also be induced in many other tissues including fibroblasts, skeletal and smooth muscle, and immune cells [155-158]. The 11 $\beta$-HSD1 enzymes are known important regulators of hormone action at the tissue level [150]. Adipocyte-derived leptin and oestrogen upregulate $11 \beta$-HSD1 $[159,160]$ to increase both intracellular and 
circulating cortisol levels. In the circulation, over $90 \%$ of cortisol is bound to corticosteroid binding globulin (CBG). It is only the unbound free portion that is able to diffuse into the cell and exert its effects.

Glucocorticoids are abundant highly widespread nuclear hormones [161,162]. They exert their actions in almost all tissues, influencing the expression of a large proportion of the human genome. Binding of the glucocorticoid to its receptor changes the transcription rates of target genes. A large number of molecules participate directly or indirectly in the signalling cascade $[161,163]$. Glucocorticoids are pivotal in regulating many aspects of resting and stress-related homeostasis. They are released as part of the stress response and have a catabolic effect to liberate substrates for mitochondrial oxidation [164].

\section{Physiological effects of cortisol}

Cortisol stimulates gluconeogenesis and fatty-acid mobilisation in the liver and adipose tissue. One of the most important effects of cortisol is that it upregulates glucose production. In the liver, cortisol increases the expression of the gluconeogenic enzymes phosphoenolpyruvate carboxykinase-C (PEPCK-C) and glucose-6-phosphatase (G6Pase), which releases glucose from glycogen into the circulation [165]. Glucocorticoids primarily act by the activation of the glucocorticoid receptor (GR) and the regulation of transcription. The GR is a ligand-regulated nuclear receptor that belongs to the steroid hormone receptor family. The GRs are expressed in almost all tissues. Upon binding by cortisol, the GR moves to the nucleus, binds specific glucocorticoid response elements (GRE) and recruits co-activators and corepressors, which can increase or decrease gene transcription [166,167]. The GR can also alter nuclear translation without the GRE [168] and cortisol can also exert non-genomic actions in stimulating endothelial nitric oxide production [169].

\section{Cortisol and metabolic syndrome}

Prolonged elevation of cortisol can lead to hyperglycaemia and insulin resistance as observed in Type 2 diabetes and metabolic syndrome [164,170,171]. Glucocorticoids directly inhibit insulin release from the $\beta$ pancreatic cells $[172,173]$. Cushing's disease or hypercortisolism is a hormonal disorder that causes elevated cortisol levels. Adverse effects linked to upregulation of the HPA axis occur in patients with Cushing's syndrome, causing outcomes such as osteoporosis, immunosuppression, hypertension, sleep disorders and glucose intolerance [174]. Other effects observed in women with high levels of cortisol include muscle wasting, striae, hirsuitism, acne, menstrual abnormalities and infertility [140]. Individuals who develop pathological states of glucocorticoid excess exhibit all the features of metabolic syndrome, however, Cushing's syndrome is rare and the circulating levels of cortisol are normal in the majority of patients with obesity and Type 2 diabetes. One hypothesis is that tissue-specific deregulation of cortisol metabolism may be involved in the intricate pathophysiology of metabolic syndrome [175] and that changes in the expression of $11 \beta$-HSD 1 increase tissue-specific levels of glucocorticoids [176,177]. Inhibitors of $11 \beta-H S D 1$ are being evaluated in clinical trials for the treatment of Type 2 diabetes. The drugs work by decreasing the amount of cortisol generated in the liver and adipose tissue, thereby reducing gluconeogenesis and fatty-acid breakdown [178]. Ketoconazole is a steroid synthesis inhibitor that lowers cortisol in Cushing's disease [179] by reducing plasma cortisol levels without affecting the CRH secretion in healthy adults [180].

\section{Cortisol levels during pregnancy}

Circulating and bound levels of cortisol both increase as gestation proceeds to levels that are similar to those detected in Cushing's syndrome, with plasma levels of cortisol reaching 2- to 3-fold higher than observed in nonpregnant women [181-184]. The rise in cortisol levels begins in week 11 and continues to rise and peak between the first and second trimester to a maintenance level during the third trimester [185]. The salivary cortisol in pregnant women is twice as high as in non-pregnant women in the third trimester $[181,186]$, and the circadian rhythm of cortisol is partly blunted $[181,186]$. Plasma ACTH levels rise throughout pregnancy reaching a peak during labour and delivery, with placental ACTH production being a significant contributor to hypercortisolism in pregnancy [181]. $\mathrm{CRH}$ is synthesized in the human syncytiotrophoblast and released into both the maternal and fetal blood in significant quantities $[187,188]$. In contrast to the hypothalamic $\mathrm{CRH}$ system, the placental production of $\mathrm{CRH}$ is stimulated by glucocorticoids [189], providing a positive feedback system, which is a unique characteristic of placental $\mathrm{CRH}$ and indicates a role for CRH in late stages of gestation [190]. Exposure to elevated cortisol levels early in the pregnancy may accelerate placental synthesis and the release of corticotrophic releasing hormone to precipitate early delivery [191]. Placental hypersecretion of CRH mid gestation has been proposed as a predictive marker of subsequent preterm delivery [192]. It has been postulated that towards the end of the gestation period CRH stimulates cortisol production in the foetal adrenal glands [193,194].

\section{The effect of reproductive hormones on cortisol levels during pregnancy}

At the onset of gestation, progesterone and oestrogen are secreted by the corpus luteum in moderate amounts. The placenta then takes over progesterone and oestrogen synthesis for the rest of the pregnancy. Progesterone secretion can increase up to 40 -fold by the third trimester during a 
normal pregnancy and oestrogens levels increase up to 30 -fold by full term. Both progesterone and oestrogen receptors are expressed in the pancreatic islets of Langerhans and regulate $\beta$-cell viability and function [195]. Progesterone has a faster association for CBG than cortisol and higher levels of progesterone during pregnancy may displace cortisol from CBG, increasing plasma cortisol [196]. Progesterone can also be converted to cortisol via 17- $\alpha$-hydroxylase and 21-hydroxylase in the adrenal glands [197].

Increasing placental oestrogen stimulates the production of CBG by the liver, therefore altering the pharmacokinetics of cortisol [181]. Fetal ACTH secretion is increased as oestrogen is secreted in increasing amounts by the placenta in late gestation [198]. Oestrogen escalates and androgens reduce basal and stimulated ACTH secretion [199]. The levels of circulating ACTH and cortisol concentrations change during the normal menstrual cycle in women, where the highest concentrations of these hormones are measured in tandem with the highest circulating levels of oestrogen [200]. Therefore, oestrogen levels rise in women either during the menstrual cycle or pregnancy, altering CBG production, upregulating $11 \beta$-HSD1 levels or directly stimulating the pituitary gland, causing an overall rise in plasma cortisol.

\section{Gestational diabetes}

One of the prenatal risk factors for ASD is gestational diabetes. During late pregnancy mothers can develop insulin resistance [201]. Gestational diabetes occurs in 2 to $3 \%$ of all pregnant women [202], although more current estimations indicate up to $14 \%$ of all pregnancies are affected by gestational diabetes depending on the test criteria used [203]. Elevated cortisol levels have been measured in pregnant women with impaired glucose tolerance or gestational diabetes [204]. Gestational diabetes is a growing health concern for both the short- and long-term outcomes for both mothers and their offspring [205]. Glucose tolerance deteriorates in all women where a diminished peripheral sensitivity to insulin develops [206]. Normal pregnancy especially the third trimester is characterised by elevated metabolic stress on maternal lipids and glucose homeostasis, which includes insulin resistance and hyperinsulinemia [207,208]. Progesterone receptors expressed in pancreatic islet cells inhibit $\beta$-cell proliferation to reduce insulin secretion and glucose tolerance during pregnancy [209]. Known risk factors for gestational diabetes include excessive weight, advanced maternal age, family history of Type 2 diabetes and a previous history of gestational diabetes [210-213]. Women with gestational diabetes have a high risk of developing Type 2 diabetes later in life [214,215]. Fetal hyperglycaemia as an outcome of maternal hyperglycaemia can contribute to excessive fetal growth [202].
However, gestational diabetes has paradoxical effects of fetal growth with outcomes of increased or decreased birth weight [216]. About $85 \%$ of term newborn infants are born with birth weights in the normal range of 2500 to $4000 \mathrm{~g}$. Among full-term infants, 7 to $8 \%$ of newborns have a birth weight of $<2500 \mathrm{~g}$ (10 percentile) and a similar percentage are born overweight (>4000 g, 90 percentile) [216].

\section{Causes of excess cortisol levels during pregnancy}

While cortisol levels rise as gestation progresses, there are events that may occur during the pregnancy that elevate cortisol further. Many of the listed prenatal risk factors for ASD have the potential to alter cortisol levels either directly through stimulating the adrenocortical cells, the HPA axis, or indirectly through modulating 11 $\beta-H S D 1$ expression. Conditions that increase cortisol production during gestation are listed below. For example, activation of cortisol production is important for a role in host response during acute or chronic stressful events such as sepsis and viral infections [217]. Also inflammatory cytokines, such as the interleukins (IL-1, IL-6) and TNF- $\alpha$ acting at the pituitary and adrenocortical levels, stimulate cortisol formation [217]. In patients with rheumatoid arthritis, the cytokines TNF- $\alpha$, IL- 6 and IL- 1 cause inflammation of the synovial joints [218], which would alter cortisol production in this cohort. Adenovirus and cytomegalovirus have been shown to sequester into the adrenocortical cells to stimulate cortisol production [219,220]. Iron deficiency has been reported to elevate cortisol levels in pregnant women through increased synthesis of $\mathrm{CRH}$, resulting in increased risk of preterm labour, hypertension and preeclampsia [221]. Additionally, haemoglobin levels are inversely correlated with IL-6 levels [222]. Uncontrolled asthma is associated with reduced placental 11 $\beta$-HSD2 activity, which significantly increases fetal cortisol levels [223]. Glucocorticoids are now the consensus treatment for preterm labour occurring between gestational weeks 24 and 34 in nearly one in ten pregnancies in the USA, to prevent the adverse consequences of respiratory distress syndrome [224]. Prenatal depression and psychological stress are associated with elevated cortisol levels, prematurity and low birth weights [225,226]. Increased waist circumference associated with advancing age, even in the absence of weight gain [227] and obesity, are associated with increased cortisol production $[228,229]$.

\section{Conditions during pregnancy that elevate cortisol levels Condition}

1. Obesity [229]

2. Infection [220]

3. Psychological stress [226]

4. Depression [225] 
5. Asthma [223]

6. Iron deficiency [221]

7. Preterm labour ${ }^{\mathrm{a}}[224]$

${ }^{a}$ Requiring dexamethasone treatment.

\section{Cortisol and the placenta}

In mammals glucocorticoids are central to fetal growth, tissue development and maturation of various organs [230]. Supraphysiological levels of glucocorticoids cause fetal growth retardation in mammalian models and humans, and reduced intrauterine growth is associated with high maternal and fetal concentrations of glucocorticoids [231,232]. Glucocorticoids are lipophilic and readily cross the placenta, and in rat studies prenatal exposure to the synthetic glucocorticoids dexamethasone or betamethasone reduces birth weight [233]. Normally, fetal physiological glucocorticoid levels are lower than the maternal levels [234]. This gradient is achieved by fetoplacental 11ß-HSD2, which metabolises cortisol [235]. This barrier is not impervious and as such a minor percentage of maternal cortisol crosses to the fetus [236]. The efficiency of placental 11 $\beta$-HSD2 varies considerably $[233,237]$ where the lowest placental $11 \beta$ HSD2 activity and presumably, highest fetal exposure to glucocorticoids, results in lower birth weights [223,237].

Some children diagnosed with ASD or who have higher scores on ASD spectrum screening have low birth weights $[20,238,239]$, which could be an outcome of elevated cortisol levels that occur during the prenatal period. Furthermore, the placenta of female fetuses have increased glucocorticoid inactivation and lower corticoid receptor density than the placentas of males [240], which may render males more vulnerable to elevated maternal cortisol levels and explain gender differences in the prevalence of ASD.

\section{Cortisol and SERT expression}

As excess cortisol is associated with many serotoninderived pathological conditions, its role in altering serotonin function should be investigated. Certainly, evidence is emerging for an effect of cortisol on SERT expression in cells and tissue. Dexamethasone, a synthetic glucocorticoid, has been demonstrated to increase the mRNA and protein expression of SERT in immortalized human Blymphoblastoid cells [241], an effect that was dependent on a region located $1.4 \mathrm{~kb}$ upstream of the $5 \mathrm{HTT}$ gene transcription site and was elevated in both polymorphisms of the 5-HTTLPR promoter sequence. Stress and elevated cortisol has been demonstrated to elevate tissue SERT expression in rodent and human studies [242-244]. In a rodent model, maternal administration of dexamethasone during gestation produced persistent increases in $\left(3 \mathrm{H}^{+}\right)$ paroxetine (SSRI) binding to SERT in the brainstem and cortex without affecting the numbers of serotonergic nerve terminals [245]. Interestingly, alterations in brain serotonin levels were not offset by changes in the fractional serotonin turnover rate [246].

Both forms of the 5-HTTLPR promoter sequence polymorphisms have been reported to be associated with ASD [113-118]. However, neither polymorphism in the promoter sequence has been demonstrated conclusively to be associated with ASD. Similarly, allelic variants within the 5-HTTLPR, have been reported, which indicates that variants within the $\mathrm{S}$ and $\mathrm{L}$ alleles occur. These variants have been investigated in a Caucasian and Japanese population, demonstrating significant ethnic differences for the distribution of alleles and genotypes [247]. However, common polymorphism/s in the 5-HTTLPR promoter sequence that confers increased subsceptibility to elevated cortisol levels in the GR, GRE or coactivator sites, should be considered as a focus of genetic studies. The GRE consensus sequence, the hexanucleotide TGTTCT, was originally proposed, however, further evidence has indicated that the GRE can involve an imperfect inverted repeat of the hexanucleotide TGTTCT with a 3-bp spacer to create a palindromic structure [248]. The GRE is very similar in nucleotide sequence to the oestrogen response element (ERE) where minor changes in base sequence for the ERE can be converted to a GRE [249,250]. Changes in the nucleotide sequence can also confer altered sensitivity to GR-induced function [249,250]. Furthermore, the GR interaction with the palindromic site promotes an allosteric change in the DNA-binding domain, to alter the protein shape and promote dimerization with a second GR monomer subunit [248]. Mutations in the GR DNAbinding domain (Ser459Ala) and D loop (Pro493Arg) causes the formation of a constitutive dimerization interface, inducing GR dimerization on a non-specific DNA [251]. Other SNPs in the GR, including ER22/23EK, $\mathrm{N} 363 \mathrm{~S}$ and BcII have been found to be associated with glucocorticoid sensitivity and stress-induced cortisol responses, and provide potential targets for investigating the genetic inheritance of ASD [252].

\section{Evidence for elevated SERT or cortisol in children with ASD}

It is the premise of this review that excessive plasma levels of cortisol during pregnancy increase the expression of the SERT transporter, to alter serotonin levels during gestation and modify prenatal neuronal development in children diagnosed with ASD. Hence the best time to measure changes in SERT expression would be immediately after birth. During infancy the SERT expression will alter according to cortisol levels. Due to the limitations of diagnosis in this cohort, most research is completed in children age 4 to 9 years or older, and as such, work to investigate neuronal SERT expression is too late, as protein levels would be highly variable. 
Subsequently, the therapeutic use of SSRIs in children with ASD has been questioned as this class of drug has been demonstrated to have limited use in this cohort. Again it would be anticipated that SSRI use would be helpful when SERT expression is highest in younger children [253]. Elevated platelet serotonin levels (or SERT mRNA) may provide a simple test of elevated SERT expression in newborn children.

Alternatively, we could appraise evidence of exposure to excess cortisol in newborn children; however, again there is little research that has been done in neonates. Reviewing the effects of extraphysiological cortisol (see Table 1), the following symptoms in newborn children could be expected: insomnia, irritability, low cortisol levels or low bone density. Two studies have measured bone density in boys diagnosed with ASD (age 4 to 14 years) and found reductions in bone mineral density or bone cortical thickness. The authors attributed these findings to low vitamin D levels or diet [254,255]. These findings did not account for the possibility that they may have started from a lower base. Also, children who are subjected to high cortisol levels in utero are at risk of developing diabetes, however little research has been reported on the long-term physical outcomes of adults with ASD [256].

\section{Conclusions}

This review investigates the potential causes of ASD and has focused on disruptions in serotonin signalling caused by elevated SERT levels during the prenatal period. Increases in membrane SERT levels are driven in utero by elevated cortisol levels. Increased cortisol in pregnant women may result in various clinical presentations including gestational diabetes, hypertension or depression. It may also be caused by excess anxiety or stress and inflammatory disorders such as asthma or infections. Further studies of excessive free cortisol levels during pregnancy should be done in women who have previously had children with ASD, or have a family history of anxiety, depression or diabetes. A standard protocol to measure free-cortisol levels in women during gestation needs to be established. Methods to measure free-cortisol levels include calculated free cortisol (Coolen's method), calculating the free-cortisol index (ratio of serum cortisol to transcortin concentrations) or quantifying salivary cortisol [217]. Cortisol is vital for fetal development with respect to maturation of lung function; however, prenatal exposure to excess glucocorticoids has also been shown to be detrimental to fetal growth and have longer-term effects related to hypertension and type II diabetes in adult life [257,258].

\section{Abbreviations}

ACTH: Adrenocorticotrophic hormone; ASD: Autism spectrum disorder; CBG: Corticosteroid binding globulin; CBP: Corticosteroid binding protein; $\mathrm{CRH}$ : Corticotrophin releasing hormone; CSF: Cerebral spinal fluid; DAT: Dopamine transporter; ERE: Estrogen response element;
G6Pase: Glucose-6-phosphatase; GR: Glucocorticoid receptor; GRE: Glucocorticoid response elements; 5-HIAA: 5-hydroxyindolacetic; 11ß-HSD: 11ß-hydroxysteroid dehydrogenase; 5-HT: 5-hydroxytryptamine; 5-HTTP: 5-hydroxytryptophan; 5-HTTLP: Serotonin transporter gene promoter region; HPA: Human hypothalamic axis; IFN- $\gamma$ : Interferon- - ; IL: Interleukin; MAPK: Mitogen-activated protein kinase; NADP(H): Nicotinamide adenine dinucleotide phosphate reduced; NET: Noradrenaline transporter; PDDNOS: Pervasive developmental disorder not otherwise specified; PET: Positron emission tomograhy; PEPCK-C: Phosphoenolpyruvate carboxykinase; PK: Protein kinase; SERT: Serotonin reuptake transporter; SNP: Single nucleotide polymorphism; SSRI: Selective serotonin reuptake inhibitor; SLC6A4: Solute carrier family 6 (neurotransmitter transporter, serotonin), member 4; TNF-a: Tumour necrosis factor-a; VNT: Variable number of tandem repeats.

\section{Competing interests}

The author has no competing interest.

Received: 4 April 2013 Accepted: 13 September 2013

Published: 8 October 2013

\section{References}

1. Zafeiriou DI, Ververi A, Vargiami E: The serotonergic system: its role in pathogenesis and early developmental treatment of autism. Curr Neuropharmacol 2009, 7:150-157.

2. Levy SE, Mandell DS, Schultz RT: Autism. Lancet 2009, 374:1627-1638.

3. Matson JL, Kozlowski AM, Matson MM: Speech deficits in persons with autism: Eitiology and symptom presentation. Res Autism Spectr Disor 2012, 6:573-577.

4. Lord C, Cook EH, Leventhal BL, Amaral DG: Autism spectrum disorders. Neuron 2000, 28:355-363.

5. Kern JK, Trivedi MH, Garver CR, Grannemann BD, Andrews AA, Savla JS, Johnson DG, Mehta JA, Schroeder JL: The pattern of sensory processing abnormalities in autism. Autism 2006, 10:480-494.

6. Giarelli E, Wiggins LD, Rice CE, Levy SE, Kirby RS, Pinto-Martin J, Mandell D: Sex differences in the evaluation and diagnosis of autism spectrum disorders among children. Disabil Health J 2010, 3:107-116.

7. Wing L, Gould J, Gillberg C: Autism spectrum disorders in the DSM-V: better or worse than the DSM-IV? Res Dev Disabil 2011, 32:768-773.

8. Blumberg SJ, Bramlett MD, Kogan MD, Schieve LA, Jones JR, Lu MC: Changes in prevalence of parent-reported autism spectrum disorder in school-aged U.S. children: 2007-2012. Natl Health Stat Report 2013, 65:1-11.

9. Pardo CA, Eberhart CG: The neurobiology of autism. Brain Pathol 2007, 17:434-447.

10. Lord C: Follow-up of two-year-olds referred for possible autism. J Child Psychol Psychiatry 1995, 36:1365-1382.

11. Baranek GT: Autism during infancy: a retrospective video analysis of sensory-motor and social behaviors at 9-12 months of age. J Autism Dev Disord 1999, 29:213-224

12. Volkmar FR, Chawarska K: Autism in infants: an update. World Psychiatr 2008, 7:19-21.

13. Zwaigenbaum L, Bryson S, Rogers T, Roberts W, Brian J, Szatmari P: Behavioral manifestations of autism in the first year of life. Int J Dev Neurosci 2005, 23:143-152.

14. Lam KS, Aman MG, Arnold LE: Neurochemical correlates of autistic disorder: a review of the literature. Res dev disabil 2006, 27:254-289.

15. DiCicco-Bloom E, Lord C, Zwaigenbaum L, Courchesne E, Dager SR, Schmitz C, Schultz RT, Crawley J, Young L: The developmental neurobiology of autism spectrum disorder. J Neurosci 2006, 26:6897-6906.

16. O'Roak BJ, State MW: Autism genetics: strategies, challenges, and opportunities. Autism Res 2008, 1:4-17.

17. Bailey A, Le-Couteur A, Gottesman I, Bolton P, Simonoff E, Yuzda E, Rutter M: Autism as a strongly genetic disorder: evidence from a British twin study. Psychol Med 1995, 25:63-77.

18. Ozonoff S, Young GS, Carter A, Messinger D, Yirmiya N, Zwaigenbaum L, Bryson S, Carver LJ, Constantino JN, Dobkins K, Hutman T, Iverson JM, Landa R, Rogers SJ, Sigman M, Stone WL: Recurrence risk for autism spectrum disorders: a baby siblings research consortium study. Pediatrics 2011, 128:e488-e495.

19. Newschaffer CJ, Fallin D, Lee NL: Heritable and nonheritable risk factors for autism spectrum disorders. Epidemiol Rev 2002, 24:137-153. 
20. Schendel $D$, Bhasin TK: Birth weight and gestational age characteristics of children with autism, including a comparison with other developmental disabilities. Pediatrics 2008, 121:1155-1164.

21. Herring S, Gray K, Taffe J, Tonge B, Sweeney D, Einfeld S: Behaviour and emotional problems in toddlers with pervasive developmental disorders and developmental delay: associations with parental mental health and family functioning. J Intellect Disabil Res 2006, 50:874-882.

22. Simonoff E, Pickles A, Charman T, Chandler S, Loucas T, Baird G: Psychiatric disorders in children with autism spectrum disorders: prevalence, comorbidity, and associated factors in a population-derived sample. J Am Acad Child Adolesc Psychiatry 2008, 47:921-929.

23. Duchan E, Patel DR: Epidemiology of autism spectrum disorders. Pediatr Clin North Am 2012, 59:27-43. ix-x.

24. Casanova MF: The minicolumnopathy of autism: $A$ link between migraine and gastrointestinal symptoms. Med Hypotheses 2008, 70:73-80.

25. Deakin J: The role of serotonin in depression and anxiety. Eur Psychiatry 1998, 13(Suppl 2):57s-63s.

26. Ohara K, Nagai M, Suzuki Y, Ochiai M: Association between anxiety disorders and a functional polymorphism in the serotonin transporter gene. Psychiatry Res 1998, 81:277-279.

27. Halperin JM, Newcorn JH, Schwartz ST, Sharma V, Siever LJ, Koda VH, Gabrie $\mathrm{S}$ : Age-related changes in the association between serotonergic function and aggression in boys with ADHD. Biol Psychiatr 1997, 41:682-689.

28. Kauffman MA, Consalvo D, Gonzalez-Moron D, Aguirre F, D'Alessio L, Kochen S: Serotonin transporter gene variation and refractory mesial temporal epilepsy with hippocampal sclerosis. Epilepsy Res 2009, 85:231-234.

29. Stefulj J, Bordukalo-Niksic T, Hecimovic H, Demarin V, Jernej B: Epilepsy and serotonin $(5 \mathrm{HT})$ : variations of $5 \mathrm{HT}$-related genes in temporal lobe epilepsy. Neurosci Lett 2010, 478:29-31.

30. Monti JM: Serotonin control of sleep-wake behavior. Sleep Med Rev 2011 15:269-281.

31. Gershon MD, Tack J: The serotonin signaling system: from basic understanding to drug development for functional Gl disorders. Gastroenterology 2007, 132:397-414.

32. Stockmeier CA: Involvement of serotonin in depression: evidence from postmortem and imaging studies of serotonin receptors and the serotonin transporter. J Psychiatr Res 2003, 37:357-373.

33. Gadow KD, DeVincent CJ, Siegal VI, Olvet DM, Kibria S, Kirsch SF, Hatchwell E: Allele-specific associations of 5-HTTLPR/rs25531 with ADHD and autism spectrum disorder. Prog Neuropsychopharmacol Biol Psychiatry 2013, 40:292-297.

34. Schuh-Hofer S, Richter M, Geworski L, Villringer A, Israel H, Wenzel R, Munz $\mathrm{DL}$, Arnold G: Increased serotonin transporter availability in the brainstem of migraineurs. J neurol 2007, 254:789-796.

35. Schain RJ, Freedman DX: Studies on 5-hydroxyindole metabolism in autistic and other mentally retarded children. J Pediatr 1961, 58:315-320.

36. Cook EH, Leventhal BL: The serotonin system in autism. Current Opin Pediatr 1996, 8:348-354.

37. Kuperman S, Beeghly JH, Burns TL, Tsai LY: Serotonin relationships of autistic probands and their first-degree relatives. J Am Acad Child Psychiatry 1985, 24:186-190.

38. Sainio EL, Pulkki K, Young SN: L-Tryptophan: Biochemical, nutritional and pharmacological aspects. Amino Acids 1996, 10:21-47.

39. Whitaker-Azmitia PM: Behavioral and cellular consequences of increasing serotonergic activity during brain development: a role in autism? Int $J$ Dev Neurosci 2005, 23:75-83.

40. Qian Y, Melikian HE, Rye DB, Levey Al, Blakely RD: Identification and characterization of antidepressant-sensitive serotonin transporter proteins using site-specific antibodies. J Neurosci 1995, 15:1261-1274.

41. Gordon J, Barnes NM: Lymphocytes transport serotonin and dopamine: agony or ecstasy? Trends Immunol 2003, 24:438-443.

42. Balkovetz DF, Tiruppathi C, Leibach FH, Mahesh VB, Ganapathy V: Evidence for an imipramine-sensitive serotonin transporter in human placental brush-border membranes. J Biol Chem 1989, 264:2195-2198.

43. Paczkowski NJ, Vuocolo HE, Bryan-Lluka LJ: Conclusive evidence for distinct transporters for 5-hydroxytryptamine and noradrenaline in pulmonary endothelial cells of the rat. Naunyn Schmiedebergs Arch Pharmacol 1996, 353:423-430.

44. Paulmann N, Grohmann M, Voigt JP, Bert B, Vowinckel J, Bader M, Skelin M, Jevsek M, Fink H, Rupnik M, Walther DJ: Intracellular serotonin modulates insulin secretion from pancreatic beta-cells by protein serotonylation. PLOS Biol 2009, 7:e1000229.
45. Schroeter S, Levey Al, Blakely RD: Polarized expression of the antidepressant-sensitive serotonin transporter in epinephrinesynthesizing chromaffin cells of the rat adrenal gland. Mol Cell Neurosci 1997, 9:170-184

46. Carneiro AM, Cook EH, Murphy DL, Blakely RD: Interactions between integrin alphallbbeta3 and the serotonin transporter regulate serotonin transport and platelet aggregation in mice and humans. J Clin Invest 2008, 118:1544-1552.

47. Murphy DL, Fox MA, Timpano KR, Moya PR, Ren-Patterson R, Andrews AM, Holmes A, Lesch KP, Wendland JR: How the serotonin story is being rewritten by new gene-based discoveries principally related to SLC6A4, the serotonin transporter gene, which functions to influence all cellular serotonin systems. Neuropharmacology 2008, 55:932-960.

48. Lesch KP, Wolozin BL, Murphy DL, Reiderer P: Primary structure of the human platelet serotonin uptake site: identity with the brain serotonin transporter. J Neurochem 1993, 60:2319-2322.

49. Vanhoutte PM, Luscher TF: Serotonin and the blood vessel wall. J Hypertens Supp/ 1986, 4:S29-S35

50. Walther DJ, Peter JU, Winter S, Holtje M, Paulmann N, Grohmann M, Vowinckel J, Alamo-Bethencourt V, Wilhelm CS, Ahnert-Hilger G, Bader M: Serotonylation of small GTPases is a signal transduction pathway that triggers platelet alpha-granule release. Cell 2003, 115:851-862.

51. Sauer WH, Berlin JA, Kimmel SE: Effect of antidepressants and their relative affinity for the serotonin transporter on the risk of myocardial infarction. Circulation 2003, 108:32-36.

52. Roose SP, Miyazaki M: Pharmacologic treatment of depression in patients with heart disease. Psychosom Med 2005, 67(Suppl 1):S54-S57.

53. Nakatani D, Sato H, Sakata Y, Shiotani I, Kinjo K, Mizuno H, Shimizu M, Ito H, Koretsune $Y$, Hirayama A, Hori M: Influence of serotonin transporter gene polymorphism on depressive symptoms and new cardiac events after acute myocardial infarction. Am Heart J 2005, 150:652-658.

54. Gershon MD, Dreyfus CF, Pickel VM, Joh TH, Reis DJ: Serotonergic neurons in the peripheral nervous system: identification in gut by immunohistochemical localization of tryptophan hydroxylase. Proc Natl Acad Sci USA 1977, 74:3086-3089.

55. Legay C, Faudon M, Hery F, Ternaux JP: 5-HT metabolism in the intestinal wall of the rat-I. Mucosa Neurochem Int 1983, 5:721-727.

56. Ormsbee HS 3rd, Fondacaro JD: Action of serotonin on the gastrointestinal tract. Proc Soc Exp Biol Med 1985, 178:333-338.

57. Martel F: Recent advances on the importance of the serotonin transporter SERT in the rat intestine. Pharmacol Res 2006, 54:73-76.

58. Azmitia EC, Whitaker-Azmitia PM: Awakening the sleeping giant: anatomy and plasticity of the brain serotonergic system. J Clin Psychiatr 1991, 52(Suppl):4-16.

59. Jacobs BL, Azmitia EC: Structure and function of the brain serotonin system. Physiol Rev 1992, 72:165-229.

60. Sundstrom E, Kolare S, Souverbie F, Samuelsson EB, Pschera H, Lunell NO, Seiger A: Neurochemical differentiation of human bulbospinal monoaminergic neurons during the first trimester. Brain Res Dev 1993, 75:1-12.

61. Lauder JM, Krebs H: Serotonin as a differentiation signal in early neurogenesis. Dev Neurosci 1978, 1:15-30.

62. Buznikov GA: The action of neurotransmitters and related substances on early embryogenesis. Pharmacol Ther 1984, 25:23-59.

63. Daws LC, Gould GG: Ontogeny and regulation of the serotonin transporter: providing insights into human disorders. Pharmacol Ther 2011, 131:61-79.

64. Cases O, Seif I, Grimsby J, Gaspar P, Chen K, Pournin S, Muller U, Aguet M, Babinet C, Shih JC, De-Maeyer E: Aggressive behavior and altered amounts of brain serotonin and norepinephrine in mice lacking MAOA. Science 1995, 268:1763-1766

65. Cases O, Vitalis T, Seif I, De-Maeyer E, Sotelo C, Gaspar P: Lack of barrels in the somatosensory cortex of monoamine oxidase A-deficient mice: role of a serotonin excess during the critical period. Neuron 1996, 16:297-307.

66. Gaspar P, Cases O, Maroteaux L: The developmental role of serotonin: news from mouse molecular genetics. Nat Rev Neurosci 2003 , 4:1002-1012.

67. Chugani DC: Role of altered brain serotonin mechanisms in autism. Mol Psychiatr 2002, 7(Suppl 2):S16-S17.

68. Chandana SR, Behen ME, Juhasz C, Muzik O, Rothermel RD, Mangner TJ, Chakraborty PK, Chugani HT, Chugani DC: Significance of abnormalities in developmental trajectory and asymmetry of cortical serotonin synthesis in autism. Int J Dev Neurosci 2005, 23:171-182. 
69. Chugani DC, Muzik O, Behen M, Rothermel R, Janisse JJ, Lee J, Chugani HT: Developmental changes in brain serotonin synthesis capacity in autistic and nonautistic children. Ann Neurol 1999, 45:287-295

70. Seifert WE Jr, Foxx JL, Butler IJ: Age effect on dopamine and serotonin metabolite levels in cerebrospinal fluid. Ann Neurol 1980, 8:38-42.

71. Hedner J, Lundell KH, Breese GR, Mueller RA, Hedner T: Developmental variations in CSF monoamine metabolites during childhood. Biol neonate 1986, 49:190-197.

72. Burgess NK, Sweeten TL, McMahon WM, Fujinami RS: Hyperserotoninemia and altered immunity in autism. J Autism Dev Disord 2006, 36:697-704.

73. Adamsen D, Meili D, Blau N, Thony B, Ramaekers V: Autism associated with low 5-hydroxyindolacetic acid in CSF and the heterozygous SLC6A4 gene Gly56Ala plus 5-HTTLPR L/L promoter variants. Mol Genet Metab 2011, 102:368-373.

74. McDougle CJ, Naylor ST, Cohen DJ, Aghajanian GK, Heninger GR, Price LH: Effects of tryptophan depletion in drug-free adults with autistic disorder. Arch Gen Psychiatr 1996, 53:993-1000.

75. Kolevzon A, Mathewson KA, Hollander E: Selective serotonin reuptake inhibitors in autism: a review of efficacy and tolerability. J Clin Psychiatr 2006, 67:407-414.

76. Ramamoorthy S, Giovanetti E, Qian Y, Blakely RD: Phosphorylation and regulation of antidepressant-sensitive serotonin transporters. J Biol Chem 1998, 273:2458-2466.

77. Rudnick G, Clark J: From synapse to vesicle: the reuptake and storage of biogenic amine neurotransmitters. Biochim Biophys Acta 1993, 1144:249-263.

78. Zhu CB, Carneiro AM, Dostmann WR, Hewlett WA, Blakely RD: p38 MAPK activation elevates serotonin transport activity via a traffickingindependent, protein phosphatase 2A-dependent process. J Biol Chem 2005, 280:15649-15658.

79. Zhu CB, Hewlett WA, Feoktistov I, Biaggioni I, Blakely RD: Adenosine receptor, protein kinase $G$, and $p 38$ mitogen-activated protein kinase-dependent up-regulation of serotonin transporters involves both transporter trafficking and activation. Mol Pharmacol 2004, 65:1462-1474.

80. Samuvel DJ, Jayanthi LD, Bhat NR, Ramamoorthy S: A role for p38 mitogen-activated protein kinase in the regulation of the serotonin transporter: evidence for distinct cellular mechanisms involved in transporter surface expression. J Neurosci 2005, 25:29-41.

81. Ramamoorthy S, Blakely RD: Phosphorylation and sequestration of serotonin transporters differentially modulated by psychostimulants. Science 1999, 285:763-766.

82. Ramamoorthy S, Shippenberg TS, Jayanthi LD: Regulation of monoamine transporters: Role of transporter phosphorylation. Pharmacol Ther 2011, 129:220-238.

83. Latorre E, Mendoza C, Matheus N, Castro M, Grasa L, Mesonero JE, Alcalde Al: IL-10 modulates serotonin transporter activity and molecular expression in intestinal epithelial cells. Cytokine 2013, 61:778-784.

84. Foley KF, Pantano C, Ciolino A, Mawe GM: IFN-gamma and TNF-alpha decrease serotonin transporter function and expression in Caco2 cells. Am J Physiol Gastrointest Liver Physiol 2007, 292:G779-G784.

85. Tsao CW, Lin YS, Chen CC, Bai CH, Wu SR: Cytokines and serotonin transporter in patients with major depression. Prog Neuropsychopharmacol Biol Psychiatry 2006, 30:899-905.

86. Daws LC: Unfaithful neurotransmitter transporters: focus on serotonin uptake and implications for antidepressant efficacy. Pharmacol Ther 2009, 121:89-99.

87. Glatt CE, DeYoung JA, Delgado S, Service SK, Giacomini KM, Edwards RH, Risch N, Freimer NB: Screening a large reference sample to identify very low frequency sequence variants: comparisons between two genes. Nat Genet 2001, 27:435-438.

88. Prasad HC, Zhu CB, McCauley JL, Samuvel DJ, Ramamoorthy S, Shelton RC, Hewlett WA, Sutcliffe JS, Blakely RD: Human serotonin transporter variants display altered sensitivity to protein kinase $\mathrm{G}$ and p38 mitogen-activated protein kinase. Proc Natl Acad Sci USA 2005, 102:11545-11550.

89. Prasad HC, Steiner JA, Sutcliffe JS, Blakely RD: Enhanced activity of human serotonin transporter variants associated with autism. Philos Trans $R$ SoC Lond B Biol Sci 2009, 364:163-173.

90. Sutcliffe JS, Delahanty RJ, Prasad HC, McCauley JL, Han Q, Jiang L, Li C, Folstein SE, Blakely RD: Allelic heterogeneity at the serotonin transporter locus (SLC6A4) confers susceptibility to autism and rigid-compulsive behaviors. Am J Hum Genet 2005, 77:265-279.
91. Ozaki N, Goldman D, Kaye WH, Plotnicov K, Greenberg BD, Lappalainen J, Rudnick G, Murphy DL: Serotonin transporter missense mutation associated with a complex neuropsychiatric phenotype. Mol Psychiatr 2003, 8:933-936.

92. Veenstra-Vanderweele J, Jessen TN, Thompson BJ, Carter M, Prasad HC, Steine JA, Sutcliffe JS, Blakely RD: Modeling rare gene variation to gain insight into the oldest biomarker in autism: construction of the serotonin transporter Gly56Ala knock-in mouse. J Neurodeve Disord 2009, 1:158-171.

93. Veenstra-VanderWeele J, Muller CL, Iwamoto H, Sauer JE, Owens WA, Shah CR, Cohen J, Mannangatti P, Jessen T, Thompson BJ, et al: Autism gene variant causes hyperserotonemia, serotonin receptor hypersensitivity, social impairment and repetitive behavior. Proc Natl Acad Sci USA 2012, 109:5469-5474.

94. Jennings KA, Sheward WJ, Harmar AJ, Sharp T: Evidence that genetic variation in $5-\mathrm{HT}$ transporter expression is linked to changes in $5-\mathrm{HT} 2 \mathrm{~A}$ receptor function. Neuropharmacology 2008, 54:776-783.

95. Esterling LE, Yoshikawa T, Turner G, Badner JA, Bengel D, Gershon ES, Berrettini WH, Detera-Wadleigh SD: Serotonin transporter (5-HTT) gene and bipolar affective disorder. Am J Med Genetics 1998, 81:37-40.

96. Li X, Zou H, Brown WT: Genes associated with autism spectrum disorder. Brain Res Bull 2012, 88:543-552.

97. Yang MS, Gill M: A review of gene linkage, association and expression studies in autism and an assessment of convergent evidence. Int J Dev Neurosci 2007, 25:69-85.

98. Heils A, Teufel A, Petri S, Stober G, Riederer P, Bengel D, Lesch KP: Allelic variation of human serotonin transporter gene expression. J Neurochem 1996, 66:2621-2624

99. Sen S, Burmeister M, Ghosh D: Meta-analysis of the association between a serotonin transporter promoter polymorphism (5-HTTLPR) and anxiety-related personality traits. Am J Med Genet B Neuropsychiatr Genet 2004, 127B:85-89.

100. Canli T, Lesch KP: Long story short: the serotonin transporter in emotion regulation and social cognition. Nat Neurosci 2007, 10:1103-1109.

101. Prasansuklab A, Poovorawan Y, Tencomnao T: Modulation of human serotonin transporter expression by 5 -HTTLPR in colon cells. Int $\mathrm{J} \mathrm{MOL}$ SCl 2011, 12:6619-6634.

102. Lesch KP, Bengel D, Heils A, Sabol SZ, Greenberg BD, Petri S, Benjamin J, Muller CR, Hamer DH, Murphy DL: Association of anxiety-related traits with a polymorphism in the serotonin transporter gene regulatory region. Science 1996, 274:1527-1531.

103. Dubertret C, Hanoun N, Ades J, Hamon M, Gorwood P: Family-based association study of the 5-HT transporter gene and schizophrenia. Int $J$ Neuropsychopharmacol 2005, 8:87-92.

104. You JS, Hu SY, Chen B, Zhang HG: Serotonin transporter and tryptophan hydroxylase gene polymorphisms in Chinese patients with generalized anxiety disorder. Psychiatr Genetics 2005, 15:7-11.

105. Gonda X, Juhasz G, Laszik A, Rihmer Z, Bagdy G: Subthreshold depression is linked to the functional polymorphism of the $5 \mathrm{HT}$ transporter gene. J Affect Disord 2005, 87:291-297.

106. Campi-Azevedo AC, Boson W, De-Marco L, Romano-Silva MA, Correa H: Association of the serotonin transporter promoter polymorphism with suicidal behavior. Mol Psychiatr 2003, 8:899-900.

107. Gaysina D, Zainullina A, Gabdulhakov R, Khusnutdinova E: The serotonin transporter gene: polymorphism and haplotype analysis in Russian suicide attempters. Neuropsychobiology 2006, 54:70-74.

108. Brune CW, Kim SJ, Salt J, Leventhal BL, Lord C, Cook EH Jr: 5-HTTLPR genotype-specific phenotype in children and adolescents with autism. Am J Psychiatr 2006, 163:2148-2156.

109. Pata C, Erdal ME, Derici E, Yazar A, Kanik A, Ulu O: Serotonin transporter gene polymorphism in irritable bowel syndrome. Am J Gastroenterol 2002, 97:1780-1784.

110. Park JM, Choi MG, Park JA, Oh JH, Cho YK, Lee IS, Kim SW, Choi KY, Chung IS: Serotonin transporter gene polymorphism and irritable bowel syndrome. Neurogastroenterol Motil 2006, 18:995-1000.

111. Anderson GM, Gutknecht L, Cohen DJ, Brailly-Tabard S, Cohen JH, Ferrari $P$, Roubertoux PL, Tordjman S: Serotonin transporter promoter variants in autism: functional effects and relationship to platelet hyperserotonemia. Mol Psychiatr 2002, 7:831-836.

112. Greenberg BD, Tolliver TJ, Huang SJ, Li Q, Bengel D, Murphy DL: Genetic variation in the serotonin transporter promoter region affects serotonin uptake in human blood platelets. Am J Med Genetics 1999, 88:83-87. 
113. Devlin B, Cook EH Jr, Coon H, Dawson G, Grigorenko EL, McMahon W, Minshew N, Pauls D, Smith M, Spence MA, et al: Autism and the serotonin transporter: the long and short of it. Mol Psychiatr 2005, 10:1110-1116.

114. Conroy J, Meally E, Kearney G, Fitzgerald M, Gill M, Gallagher L: Serotonin transporter gene and autism: a haplotype analysis in an Irish autistic population. Mol Psychiatr 2004, 9:587-593.

115. McCauley JL, Olson LM, Dowd M, Amin T, Steele A, Blakely RD, Folstein SE, Haines JL, Sutcliffe JS: Linkage and association analysis at the serotonin transporter (SLC6A4) locus in a rigid-compulsive subset of autism. Am J Med Genet B Neuropsychiatr Genet 2004, 127B:104-112.

116. Cook EH Jr, Courchesne R, Lord C, Cox NJ, Yan S, Lincoln A, Haas R, Courchesne $E$, Leventhal BL: Evidence of linkage between the serotonin transporter and autistic disorder. Mole Psychiatry 1997, 2:247-250.

117. Yirmiya N, Pilowsky T, Nemanov L, Arbelle S, Feinsilver T, Fried I, Ebstein RP Evidence for an association with the serotonin transporter promoter region polymorphism and autism. Am J Med Gen 2001, 105:381-386.

118. Klauck SM, Poustka F, Benner A, Lesch KP, Poustka A: Serotonin transporter (5-HTT) gene variants associated with autism? Hum Mol Genet 1997, 6:2233-2238.

119. Sykes NH, Lamb JA: Autism: the quest for the genes. Expert Rev Mole Med 2007, 9:1-15.

120. Ramoz N, Reichert JG, Corwin TE, Smith CJ, Silverman JM, Hollander E, Buxbaum JD: Lack of evidence for association of the serotonin transporter gene SLC6A4 with autism. Biol Psychiatry 2006, 60:186-191.

121. Zhong N, Ye L, Ju W, Brown WT, Tsiouris J, Cohen I: 5-HTTLPR variants not associated with autistic spectrum disorders. Neurogenetics 1999, 2:129-131.

122. Wendland JR, Kruse MR, Cromer KR, Murphy DL: A large case-control study of common functional SLC6A4 and BDNF variants in obsessivecompulsive disorder. Neuropsychopharmacology 2007, 32:2543-2551.

123. Moya PR, Wendland JR, Rubenstein LM, Timpano KR, Heiman GA, Tischfield JA, King RA, Andrews AM, Ramamoorthy S, McMahon FJ, Murphy DL: Common and rare alleles of the serotonin transporter gene, SLC6A4, associated with Tourette's disorder. Mov Disord 2013. Epub 2013 Apr 29.

124. Leonard H, De-Klerk N, Bourke J, Bower C: Maternal health in pregnancy and intellectual disability in the offspring: a population-based study. Annals Epidemiol 2006, 16:448-454.

125. Wilkerson DS, Volpe AG, Dean RS, Titus JB: Perinatal complications as predictors of infantile autism. Int J Neurosci 2002, 112:1085-1098.

126. Krakowiak P, Walker CK, Bremer AA, Baker AS, Ozonoff S, Hansen RL, Hertz-Picciotto I: Maternal metabolic conditions and risk for autism and other neurodevelopmental disorders. Pediatrics 2012, 129:e1121-e1128.

127. Gardener H, Spiegelman D, Buka SL: Prenatal risk factors for autism: comprehensive meta-analysis. Br J Psychiatry 2009, 195:7-14

128. Glasson EJ, Bower C, Petterson B, De-Klerk N, Chaney G, Hallmayer JF: Perinatal factors and the development of autism: a population study. Arch Gen Psychiatry 2004, 61:618-627.

129. Rocklin RE: Asthma, asthma medications and their effects on maternal/ fetal outcomes during pregnancy. Reproductive Toxicol (Elmsford, NY) 2011, 32:189-197.

130. Comi AM, Zimmerman AW, Frye VH, Law PA, Peeden JN: Familial clustering of autoimmune disorders and evaluation of medical risk factors in autism. J Child Neurol 1999, 14:388-394.

131. Larsson HJ, Eaton WW, Madsen KM, Vestergaard M, Olesen AV, Agerbo E, Schendel D, Thorsen P, Mortensen PB: Risk factors for autism: perinatal factors, parental psychiatric history, and socioeconomic status. Am J Epidemiol 2005, 161:916-925. discussion 926-918.

132. Moore GS, Kneitel AW, Walker CK, Gilbert WM, Xing G: Autism risk in small- and large-for-gestational-age infants. Am J Obstetrics Gynecol 2012, 206:314. e311-319.

133. Sapse AT: Cortisol, high cortisol diseases and anti-cortisol therapy. Psychoneuroendocrinol 1997, 22(Suppl 1):S3-S10.

134. Field T, Diego M: Cortisol: the culprit prenatal stress variable. Int J Neurosci 2008, 118:1181.

135. Reynolds RM: Glucocorticoid excess and the developmental origins of disease: two decades of testing the hypothesis-2012 Curt Richter Award Winner. Psychoneuroendocrinol 2013, 38:1-11.

136. Ziegler DK, Hassanein RS, Kodanaz A, Meek JC: Circadian rhythms of plasma cortisol in migraine. J Neurol Neurosurgery Psychiatry 1979, 42:741-748.

137. Cowen PJ: Cortisol, serotonin and depression: all stressed out? Brit J PsychiatryJ Mental Sci 2002, 180:99-100.
138. Muck-Seler D, Pivac N, Jakovljevic M, Brzovic Z: Platelet serotonin, plasma cortisol, and dexamethasone suppression test in schizophrenic patients. Biol Psychiatry 1999, 45:1433-1439.

139. Dahl R: Systemic side effects of inhaled corticosteroids in patients with asthma. Respir Med 2006, 100:1307-1317.

140. Bertagna X, Guignat L, Groussin L, Bertherat J: Cushing's disease. Best Pract Res Clin Endocrinol Metab 2009, 23:607-623.

141. Baqai A, Bal R: The mechanism of action and side effects of epidural steroids. Tech Reg Anes Pain Manage 2009, 13:205-2011.

142. Australian Medicines Handbook. 2013.

143. Warne JP: Shaping the stress response: interplay of palatable food choices, glucocorticoids, insulin and abdominal obesity. Mole Cell Endocrinol 2009, 300:137-146.

144. Russell GM, Henley DE, Leendertz J, Douthwaite JA, Wood SA, Stevens A, Woltersdorf WW, Peeters BW, Ruigt GS, White A, Veldhuis JD, Lightman SL: Rapid glucocorticoid receptor-mediated inhibition of hypothalamic-pituitary-adrenal ultradian activity in healthy males. J Neurosci J Soc Neurosci 2010, 30:6106-6115.

145. Lightman SL, Wiles CC, Atkinson HC, Henley DE, Russell GM, Leendertz JA, McKenna MA, Spiga F, Wood SA, Conway-Campbell BL: The significance of glucocorticoid pulsatility. Eur J Pharmacol 2008, 583:255-262

146. Jacobson L, Sapolsky R: The role of the hippocampus in feedback regulation of the hypothalamic-pituitary-adrenocortical axis. Endocrine Rev 1991, 12:118-134

147. Smith SM, Vale WW: The role of the hypothalamic-pituitary-adrenal axis in neuroendocrine responses to stress. Dialogues Clin Neurosci 2006, 8:383-395.

148. Chrousos GP: The hypothalamic-pituitary-adrenal axis and immune-mediated inflammation. N England J Med 1995, 332:1351-1362.

149. Smith AK, Dimulescu I, Falkenberg VR, Narasimhan S, Heim C, Vernon SD, Rajeevan MS: Genetic evaluation of the serotonergic system in chronic fatigue syndrome. Psychoneuroendocrinol 2008, 33:188-197.

150. Cooper MS, Stewart PM: 11Beta-hydroxysteroid dehydrogenase type 1 and its role in the hypothalamus-pituitary-adrenal axis, metabolic syndrome, and inflammation. J Clin Endocrinol Metab 2009, 94:4645-4654.

151. Milagro Fl, Campion J, Martinez JA: 11-Beta hydroxysteroid dehydrogenase type 2 expression in white adipose tissue is strongly correlated with adiposity. J Steroid Biochem Mol Biol 2007, 104:81-84.

152. Funder JW, Pearce PT, Smith R, Smith Al: Mineralocorticoid action: target tissue specificity is enzyme, not receptor, mediated. Science 1988 242:583-585.

153. Al Bakir M, Butt AN, Swaminathan R: Circulating 11 beta-hydroxysteroid dehydrogenase type 1 mRNA and cardiovascular risk factors. Ann NY Acad Sci 2008, 1137:283-289.

154. Jamieson PM, Walker BR, Chapman KE, Andrew R, Rossiter S, Seckl JR: 11 beta-hydroxysteroid dehydrogenase type 1 is a predominant 11 beta-reductase in the intact perfused rat liver. J Endocrinol 2000, 165:685-692.

155. Hardy RS, Filer A, Cooper MS, Parsonage G, Raza K, Hardie DL, Rabbitt EH, Stewart PM, Buckley CD, Hewison M: Differential expression, function and response to inflammatory stimuli of 11 beta-hydroxysteroid dehydrogenase type 1 in human fibroblasts: a mechanism for tissue-specific regulation of inflammation. Arthritis Res Therapy 2006, 8:R108.

156. Thieringer R, Le-Grand CB, Carbin L, Cai TQ, Wong B, Wright SD, Hermanowski-Vosatka A: 11 Beta-hydroxysteroid dehydrogenase type 1 is induced in human monocytes upon differentiation to macrophages. J Immunol (Baltimore, Md: 1950) 2001, 167:30-35.

157. Cai TQ, Wong B, Mundt SS, Thieringer R, Wright SD, Hermanowski-Vosatka A: Induction of 11 beta-hydroxysteroid dehydrogenase type 1 but not -2 in human aortic smooth muscle cells by inflammatory stimuli. J Steroid Biochem Mol Biol 2001, 77:117-122.

158. Jang C, Obeyesekere VR, Alford FP, Inder WJ: Skeletal muscle 11 beta hydroxysteroid dehydrogenase type 1 activity is upregulated following elective abdominal surgery. Euro J Endocrinol/Euro Fed Endo Soc 2009, 160:249-255.

159. Dieudonne MN, Sammari A, Dos-Santos E, Leneveu MC, Giudicelli Y, Pecquery R: Sex steroids and leptin regulate 11 beta-hydroxysteroid dehydrogenase I and P450 aromatase expressions in human preadipocytes: Sex specificities. J Steroid Biochem Mole Biol 2006, 99:189-196.

160. Paulsen SK, Pedersen SB, Fisker S, Richelsen B: 11Beta-HSD type 1 expression in human adipose tissue: impact of gender, obesity, and fat localization. Obesity (Silver Spring, Md) 2007, 15:1954-1960. 
161. Franchimont D, Kino T, Galon J, Meduri GU, Chrousos G: Glucocorticoids and inflammation revisited: the state of the art. NIH clinical staff conference. Neuroimmunomodulation 2002, 10:247-260.

162. Chrousos GP, Charmandari E, Kino T: Glucocorticoid action networks-an introduction to systems biology. J Clin eEndocrinol Metab 2004, 89:563-564.

163. Kino T, De-Martino MU, Charmandari E, Mirani M, Chrousos GP: Tissue glucocorticoid resistance/hypersensitivity syndromes. I Steroid Biochem Mol Biol 2003, 85:457-467.

164. Gathercole LL, Stewart PM: Targeting the pre-receptor metabolism of cortisol as a novel therapy in obesity and diabetes. J Steroid Biochem Mol Biol 2010, 122:21-27.

165. Chakravarty K, Cassuto H, Reshef L, Hanson RW: Factors that control the tissue-specific transcription of the gene for phosphoenolpyruvate carboxykinase-C. Crit Rev Biochem Mol Biol 2005, 40:129-154.

166. Morishima Y, Kanelakis KC, Murphy PJ, Lowe ER, Jenkins GJ, Osawa Y, Sunahara RK, Pratt WB: The hsp90 cochaperone p23 is the limiting component of the multiprotein hsp90/hsp70-based chaperone system in vivo where it acts to stabilize the client protein: hsp90 complex. J Biol Chem 2003, 278:48754-48763.

167. Pratt WB, Toft DO: Steroid receptor interactions with heat shock protein and immunophilin chaperones. Endocrine Rev 1997, 18:306-360.

168. Barnes PJ, Karin M: Nuclear factor-kappaB: a pivotal transcription factor in chronic inflammatory diseases. N England J Med 1997, 336:1066-1071.

169. Hafezi-Moghadam A, Simoncini T, Yang Z, Limbourg FP, Plumier JC, Rebsamen MC, Hsieh CM, Chui DS, Thomas KL, Prorock AJ, et al: Acute cardiovascular protective effects of corticosteroids are mediated by non-transcriptional activation of endothelial nitric oxide synthase. Nat Med 2002, 8:473-479.

170. Anagnostis P, Athyros VG, Tziomalos K, Karagiannis A, Mikhailidis DP: Clinical review: The pathogenetic role of cortisol in the metabolic syndrome: $a$ hypothesis. J Clin Endocrinol Metab 2009, 94:2692-2701.

171. Campion J, Martinez JA: Ketoconazole, an antifungal agent, protects against adiposity induced by a cafeteria diet. Hormone Metab Res 2004, 36:485-491.

172. Delaunay F, Khan A, Cintra A, Davani B, Ling ZC, Andersson A, Ostenson CG, Gustafsson J, Efendic S, Okret S: Pancreatic beta cells are important targets for the diabetogenic effects of glucocorticoids. J Clin Invest 1997 100:2094-2098.

173. Lambillotte C, Gilon P, Henquin JC: Direct glucocorticoid inhibition of insulin secretion. An in vitro study of dexamethasone effects in mouse islets. J Clin Invest 1997, 99:414-423.

174. Chrousos GP: Is 11 beta-hydroxysteroid dehydrogenase type 1 a good therapeutic target for blockade of glucocorticoid actions? Proc Natl Acad Sci USA 2004, 101:6329-6330.

175. Espindola-Antunes D, Kater CE: Adipose tissue expression of 11 beta-hydroxysteroid dehydrogenase type 1 in Cushing's syndrome and in obesity. Arq Bras Endocrinol Metabol 2007, 51:1397-1403.

176. Bujalska IJ, Kumar S, Stewart PM: Does central obesity reflect "Cushing's disease of the omentum"? Lancet 1997, 349:1210-1213.

177. Walker BR, Connacher AA, Lindsay RM, Webb DJ, Edwards CR: Carbenoxolone increases hepatic insulin sensitivity in man: a novel role for 11-oxosteroid reductase in enhancing glucocorticoid receptor activation. J Clin Endocrinol Metab 1995, 80:3155-3159.

178. Harno E, White A: Will treating diabetes with 11 beta-HSD1 inhibitors affect the HPA axis? TEM 2010, 21:619-627.

179. Loli P, Berselli ME, Tagliaferri M: Use of ketoconazole in the treatment of Cushing's syndrome. J Clin Endocrinol Metab 1986, 63:1365-1371.

180. Deuschle M, Lecei O, Stalla GK, Landgraf R, Hamann B, Lederbogen F, Uhr M, Luppa P, Maras A, Colla M, Heuser I: Steroid synthesis inhibition with ketoconazole and its effect upon the regulation of the hypothalamus-pituitary-adrenal system in healthy humans. Neuropsychopharmacology 2003, 28:379-383.

181. Lindsay JR, Nieman LK: The hypothalamic-pituitary-adrenal axis in pregnancy: challenges in disease detection and treatment. Endocr Rev 2005, 26:775-799.

182. Vilar L, Freitas Mda C, Lima LH, Lyra R, Kater CE: Cushing's syndrome in pregnancy: an overview. Ara Bras Endocrinol Metabol 2007, 51:1293-1302.

183. Demey-Ponsart E, Foidart JM, Sulon J, Sodoyez JC: Serum CBG, free and total cortisol and circadian patterns of adrenal function in normal pregnancy. J Steroid Biochem 1982, 16:165-169.
184. Odagiri E, Ishiwatari N, Abe Y, Jibiki $K$, Adachi T, Demura R, Demura $H$, Shizume K: Hypercortisolism and the resistance to dexamethasone suppression during gestation. Endocrinol Jpn 1988, 35:685-690.

185. Nolten WE, Rueckert PA: Elevated free cortisol index in pregnancy: possible regulatory mechanisms. Am J Obstet Gynecol 1981, 139:492-498.

186. Scott EM, McGarrigle HH, Lachelin GC: The increase in plasma and saliva cortisol levels in pregnancy is not due to the increase in corticosteroid-binding globulin levels. J Clin Endocrinol Metab 1990, 71:639-644

187. Nodwell A, Carmichael L, Fraser M, Challis J, Richardson B: Placental release of corticotrophin-releasing hormone across the umbilical circulation of the human newborn. Placenta 1999, 20:197-202.

188. Okamoto E, Takagi T, Azuma C, Kimura T, Tokugawa Y, Mitsuda N, Saji F Tanizawa O: Expression of the corticotropin-releasing hormone $(\mathrm{CRH})$ gene in human placenta and amniotic membrane. Horm Metab Res 1990, 22:394-397.

189. Robinson BG, Emanuel RL, Frim DM, Majzoub JA: Glucocorticoid stimulates expression of corticotropin-releasing hormone gene in human placenta. Proc Natl Acad Sci USA 1988, 85:5244-5248.

190. Challis JRG, Matthews SG, Gibb W, Lye SJ: Endocrine and paracrine regulation of birth at term and preterm. Endocr Rev 2000, 21:514-550.

191. Sandman CA, Glynn L, Schetter CD, Wadhwa P, Garite T, Chicz-DeMet A Hobel C: Elevated maternal cortisol early in pregnancy predicts third trimester levels of placental corticotropin releasing hormone $(\mathrm{CRH})$ : priming the placental clock. Peptides 2006, 27:1457-1463.

192. Petraglia F, Imperatore A, Challis JR: Neuroendocrine mechanisms in pregnancy and parturition. Endocr Rev 2010, 31:783-816.

193. Sirianni R, Mayhew BA, Carr BR, Parker CR Jr, Rainey WE: Corticotropin-releasing hormone $(\mathrm{CRH})$ and urocortin act through type $1 \mathrm{CRH}$ receptors to stimulate dehydroepiandrosterone sulfate production in human fetal adrenal cells. J Clin Endocrinol Metab 2005, 90:5393-5400.

194. Rainey WE, Rehman KS, Carr BR: The human fetal adrenal: making adrenal androgens for placental estrogens. Semin Reprod Med 2004, 22:327-336.

195. Nadal A, Alonso-Magdalena P, Soriano S, Ropero AB, Quesada I: The role of oestrogens in the adaptation of islets to insulin resistance. J Physiol 2009, 587:5031-5037.

196. Stroupe SD, Gray RD, Westphal U: Steroid-protein interactions. Kinetics of binding of cortisol and progesterone to human corticosteroid-binding globulin. FEBS Lett 1978, 86:61-64.

197. Swart P, Engelbrecht Y, Bellstedt DU, De-Villiers CA, Dreesbeimdieke C: The effect of cytochrome b5 on progesterone metabolism in the ovine adrenal. Endocr Res 1995, 21:297-306

198. Wood CE: Estrogen/hypothalamus-pituitary-adrenal axis interactions in the fetus: the interplay between placenta and fetal brain. J Soc Gynecol Investig 2005, 12:67-76.

199. Burgess $\mathrm{LH}$, Handa $\mathrm{R}$ : Chronic estrogen-induced alterations in adrenocorticotropin and corticosterone secretion, and glucocorticoid receptor-mediated functions in female rats. Endocrinology 1992, 131:1261-1269.

200. Viau V, Meaney MJ: Variations in the hypothalamic-pituitary-adrenal response to stress during the estrous cycle in the rat. Endocrinology 1991, 129:2503-2511.

201. Catalano PM, Huston L, Amini SB, Kalhan SC: Longitudinal changes in glucose metabolism during pregnancy in obese women with normal glucose tolerance and gestational diabetes mellitus. Am J Obstet Gynecol 1999, 180:903-916.

202. Gabbe SG: Gestational diabetes mellitus. N Engl J Med 1986, 315:1025-1026.

203. American Diabetes Association: Gestational diabetes mellitus. Diabetes Care 2004, 27(1):S88-S90.

204. Ahmed SA, Shalayel MH: Role of cortisol in the deterioration of glucose tolerance in Sudanese pregnant women. East Afr Med J 1999, 76:465-467.

205. Zhang C, Ning Y: Effect of dietary and lifestyle factors on the risk of gestational diabetes: review of epidemiologic evidence. Am J Clin Nutr 2011, 94:1975S-1979S.

206. Kuhl C: Glucose metabolism during and after pregnancy in normal and gestational diabetic women. 1. Influence of normal pregnancy on serum glucose and insulin concentration during basal fasting conditions and after a challenge with glucose. Acta Endocrinol (Copenh) 1975, 79:709-719.

207. Buchanan TA, Xiang AH: Gestational diabetes mellitus. J Clin Invest 2005, 115:485-491.

208. Catalano PM, Tyzbir ED, Wolfe RR, Calles J, Roman NM, Amini SB, Sims EA: Carbohydrate metabolism during pregnancy in control subjects and women with gestational diabetes. Am J Physiol 1993, 264:E60-E67. 
209. Branisteanu DD, Mathieu C: Progesterone in gestational diabetes mellitus: guilty or not guilty? TEM 2003, 14:54-56.

210. Ben-Haroush A, Yogev Y, Hod M: Epidemiology of gestational diabetes mellitus and its association with Type 2 diabetes. Diabet Med 2004, 21:103-113.

211. Metzger BE, Buchanan TA, Coustan DR, De-Leiva A, Dunger DB, Hadden DR, Hod M, Kitzmiller JL, Kjos SL, Oats JN, et al: Summary and recommendations of the fifth international workshop-conference on gestational diabetes mellitus. Diabetes Care 2007, 30(Suppl 2):S251-S260.

212. Berkowitz GS, Lapinski RH, Wein R, Lee D: Race/ethnicity and other risk factors for gestational diabetes. Am J Epidemiol 1992, 135:965-973.

213. Solomon CG, Willett WC, Carey VJ, Rich-Edwards J, Hunter DJ, Colditz GA, Stampfer MJ, Speizer FE, Spiegelman D, Manson JE: A prospective study of pregravid determinants of gestational diabetes mellitus. JAMA 1997, 278:1078-1083.

214. Damm P, Kuhl C, Bertelsen A, Molsted-Pedersen L: Predictive factors for the development of diabetes in women with previous gestational diabetes mellitus. Am J Obstet Gynecol 1992, 167:607-616.

215. Peters RK, Kjos SL, Xiang A, Buchanan TA: Long-term diabetogenic effect of single pregnancy in women with previous gestational diabetes mellitus. Lancet 1996, 347:227-230.

216. Ornoy A: Prenatal origin of obesity and their complications: gestational diabetes, maternal overweight and the paradoxical effects of fetal growth restriction and macrosomia. Reprod Toxicol 2011, 32:205-212

217. Arafah BM: Hypothalamic pituitary adrenal function during critical illness: limitations of current assessment methods. J Clin Endocrinol Metab 2006, 91:3725-3745.

218. Choy E: Understanding the dynamics: pathways involved in the pathogenesis of rheumatoid arthritis. Rheumatology (Oxford) 2012, 5(51):v3-v11.

219. Trevisan M, Matkovic U, Cusinato R, Toppo S, Palu G, Barzon L: Human cytomegalovirus productively infects adrenocortical cells and induces an early cortisol response. J Cell Physiol 2009, 221:629-641.

220. Matkovic U, Pacenti M, Trevisan M, Palu G, Barzon L: Investigation on human adrenocortical cell response to adenovirus and adenoviral vector infection. J Cell Physiol 2009, 220:45-57.

221. Allen LH: Biological mechanisms that might underlie iron's effects on fetal growth and preterm birth. J Nutr 2001, 131:581S-589S.

222. Nikolaisen C, Figenschau Y, Nossent JC: Anemia in early rheumatoid arthritis is associated with interleukin 6-mediated bone marrow suppression, but has no effect on disease course or mortality. J Rheumatol 2008, 35:380-386.

223. Murphy VE, Zakar T, Smith R, Giles WB, Gibson PG, Clifton VL: Reduced 11 beta-hydroxysteroid dehydrogenase type 2 activity is associated with decreased birth weight centile in pregnancies complicated by asthma. J Clin Endocrinol Metab 2002, 87:1660-1668.

224. Matthews SG, Owen D, Banjanin S, Andrews MH: Glucocorticoids, hypothalamo-pituitary-adrenal (HPA) development, and life after birth. Endocr Res 2002, 28:709-718.

225. Field T, Diego M, Hernandez-Reif M: Prenatal depression effects and interventions: a review. Infant Behav Dev 2010, 33:409-418.

226. Urizar GG Jr, Munoz RF: Impact of a prenatal cognitive-behavioral stress management intervention on salivary cortisol levels in low-income mothers and their infants. Psychoneuroendocrinology 2011, 36:1480-1494.

227. Stevens J, Katz EG, Huxley RR: Associations between gender, age and waist circumference. Eur J Clin Nutr 2010, 64:6-15.

228. Muhtz C, Zyriax BC, Klahn T, Windler E, Otte C: Depressive symptoms and metabolic risk: effects of cortisol and gender.

Psychoneuroendocrinology 2009, 34:1004-1011.

229. Ford SP, Zhang L, Zhu M, Miller MM, Smith DT, Hess BW, Moss GE, Nathanielsz PW, Nijland MJ: Maternal obesity accelerates fetal pancreatic beta-cell but not alpha-cell development in sheep: prenatal consequences. Am J Physiol Regul Integr Comp Physiol 2009, 297:R835-R843.

230. Seckl JR, Holmes MC: Mechanisms of disease: glucocorticoids, their placental metabolism and fetal 'programming' of adult pathophysiology. t Clin Pract Endocrinol Metab 2007, 3:479-488.

231. Goland RS, Tropper PJ, Warren WB, Stark RI, Jozak SM, Conwell IM: Concentrations of corticotrophin-releasing hormone in the umbilical-cord blood of pregnancies complicated by pre-eclampsia. Reprod Fertil Dev 1995, 7:1227-1230.

232. McTernan CL, Draper N, Nicholson $H$, Chalder SM, Driver P, Hewison M, Kilby MD, Stewart PM: Reduced placental 11 beta-hydroxysteroid dehydrogenase type 2 mRNA levels in human pregnancies complicated by intrauterine growth restriction: an analysis of possible mechanisms. J Clin Endocrinol Metab 2001, 86:4979-4983.

233. Benediktsson R, Lindsay RS, Noble J, Seckl JR, Edwards CR: Glucocorticoid exposure in utero: new model for adult hypertension. Lancet 1993, 341:339-341.

234. Beitins IZ, Bayard F, Ances IG, Kowarski A, Migeon CJ: The metabolic clearance rate, blood production, interconversion and transplacental passage of cortisol and cortisone in pregnancy near term. Pediatr Res 1973, 7:509-519.

235. Brown RW, Chapman KE, Kotelevtsev Y, Yau JL, Lindsay RS, Brett L, Leckie C, Murad P, Lyons V, Mullins JJ, Edwards CR, Seckl JR: Cloning and production of antisera to human placental 11 beta-hydroxysteroid dehydrogenase type 2. Biochem J 1996, 313(Pt 3):1007-1017.

236. Benediktsson R, Calder AA, Edwards CR, Seckl JR: Placental 11 beta-hydroxysteroid dehydrogenase: a key regulator of fetal glucocorticoid exposure. Clin Endocrinol 1997, 46:161-166.

237. Stewart PM, Rogerson FM, Mason Jl: Type 211 beta-hydroxysteroid dehydrogenase messenger ribonucleic acid and activity in human placenta and fetal membranes: its relationship to birth weight and putative role in fetal adrenal steroidogenesis. $J$ Clin Endocrinol Metab 1995, 80:885-890.

238. Indredavik MS, Vik T, Heyerdahl S, Kulseng S, Fayers P, Brubakk AM: Psychiatric symptoms and disorders in adolescents with low birth weight. Arch Dis Child Fetal Neonatal Ed 2004, 89:F445-F450.

239. Pinto-Martin JA, Levy SE, Feldman JF, Lorenz JM, Paneth N, Whitaker AH: Prevalence of autism spectrum disorder in adolescents born weighing <2000 grams. Pediatrics 2011, 128:883-891.

240. Clifton VL, Murphy VE: Maternal asthma as a model for examining fetal sex-specific effects on maternal physiology and placental mechanisms that regulate human fetal growth. Placenta 2004, 25(A):S45-52.

241. Glatz K, Mossner R, Heils A, Lesch KP: Glucocorticoid-regulated human serotonin transporter (5-HTT) expression is modulated by the $5-\mathrm{HTT}$ gene-promotor-linked polymorphic region. J Neurochem 2003, 86:1072-1078.

242. Tafet GE, Toister-Achituv M, Shinitzky M: Enhancement of serotonin uptake by cortisol: a possible link between stress and depression. Cogn Affect Behav Neurosci 2001, 1:96-104.

243. Couch Y, Anthony DC, Dolgov O, Revischin A, Festoff B, Santos Al, Steinbusch HW, Strekalova T: Microglial activation, increased TNF and SERT expression in the prefrontal cortex define stress-altered behaviour in mice susceptible to anhedonia. Brain Behav Immun 2013, 29:136-146.

244. Zhang J, Fan Y, Li Y, Zhu H, Wang L, Zhu MY: Chronic social defeat up-regulates expression of the serotonin transporter in rat dorsal raphe nucleus and projection regions in a glucocorticoid-dependent manner. J Neurochem 2012, 123:1054-1068.

245. Slotkin TA, Barnes GA, McCook EC, Seidler FJ: Programming of brainstem serotonin transporter development by prenatal glucocorticoids. Brain Res Dev Brain Res 1996, 93:155-161.

246. Slotkin TA, Kreider ML, Tate CA, Seidler FJ: Critical prenatal and postnatal periods for persistent effects of dexamethasone on serotonergic and dopaminergic systems. Neuropsychopharmacology 2006, 31:904-911.

247. Nakamura M, Ueno S, Sano A, Tanabe H: The human serotonin transporter gene linked polymorphism (5-HTTLPR) shows ten novel allelic variants. Mol Psychiatry 2000, 5:32-38.

248. Merkulov VM, Merkulova TI: Structural variants of glucocorticoid receptor binding sites and different versions of positive glucocorticoid responsive elements: Analysis of GR-TRRD database. J Steroid Biochem Mol Biol 2009, 115:1-8.

249. Klock G, Strahle U, Schutz G: Oestrogen and glucocorticoid responsive elements are closely related but distinct. Nature 1987, 329:734-736.

250. Martinez E, Givel F, Wahli W: The estrogen-responsive element as an inducible enhancer: DNA sequence requirements and conversion to a glucocorticoid-responsive element. EMBO J 1987, 6:3719-3727.

251. Van-Tilborg MA, Lefstin JA, Kruiskamp M, Teuben J, Boelens R, Yamamoto $\mathrm{KR}$, Kaptein R: Mutations in the glucocorticoid receptor DNA-binding domain mimic an allosteric effect of DNA. J Mol Biol 2000, 301:947-958.

252. Derijk RH, Van-Leeuwen N, Klok MD, Zitman FG: Corticosteroid receptor-gene variants: modulators of the stress-response and implications for mental health. Eur J Pharmacol 2008, 585:492-501.

253. Bethea TC, Sikich L: Early pharmacological treatment of autism: a rationale for developmental treatment. Biol Psychiatry 2007, 61:521-537. 
254. Neumeyer AM, Gates A, Ferrone C, Lee H, Misra M: Bone density in peripubertal boys with autism spectrum disorders. Autism Dev Disord 2013, 43:1623-1629.

255. Hediger ML, England L, Molloy CA, Yu KF, Manning-Courtney P, Mills JL: Reduced bone cortical thickness in boys with autism or autism spectrum disorder. Autism Dev Disord 2008, 38:848-856.

256. Bailey AJ: Autism in adults. Autism Res J Int 2012, 5:1-2.

257. Seckl JR: Glucocorticoids, feto-placental 11 beta-hydroxysteroid dehydrogenase type 2 , and the early life origins of adult disease. Steroids 1997, 62:89-94.

258. Dodic M, Peers A, Coghlan JP, Wintour M: Can excess glucocorticoid, predispose to cardiovascular and metabolic disease in middle Age? TEM 1999, 10:86-91.

doi:10.1186/2040-2392-4-37

Cite this article as: Rose'Meyer: A review of the serotonin transporter and prenatal cortisol in the development of autism spectrum disorders. Molecular Autism 2013 4:37.

\section{Submit your next manuscript to BioMed Central and take full advantage of:}

- Convenient online submission

- Thorough peer review

- No space constraints or color figure charges

- Immediate publication on acceptance

- Inclusion in PubMed, CAS, Scopus and Google Scholar

- Research which is freely available for redistribution 